\title{
Sphingosine-coating of plastic surfaces prevents ventilator-associated pneumonia
}

\author{
Aaron P. Seitz ${ }^{1}$. Fabian Schumacher ${ }^{2,3}$. Jennifer Baker ${ }^{1} \cdot$ Matthias Soddemann $^{3} \cdot$ Barbara Wilker $^{3}$. \\ Charles C. Caldwell ${ }^{1,4} \cdot$ Ryan M. Gobble $^{1} \cdot$ Markus Kamler $^{5} \cdot$ Katrin Anne Becker $^{3} \cdot$ Sascha Beck $^{6} \cdot$ Burkhard Kleuser $^{2}$. \\ Michael J. Edwards ${ }^{1} \cdot$ Erich Gulbins ${ }^{1,3}$
}

Received: 18 February 2019 / Revised: 1 May 2019 / Accepted: 20 May 2019 / Published online: 20 June 2019

(C) The Author(s) 2019

\begin{abstract}
Ventilator-associated pneumonia (VAP) is a major cause of morbidity and mortality in critically ill patients. Here, we employed the broad antibacterial effects of sphingosine to prevent VAP by developing a novel method of coating surfaces of endotracheal tubes with sphingosine and sphingosine analogs. Sphingosine and phytosphingosine coatings of endotracheal tubes prevent adherence and mediate killing of Pseudomonas aeruginosa, Acinetobacter baumannii, and Staphylococcus aureus, even in biofilms. Most importantly, sphingosine-coating of endotracheal tubes also prevented P. aeruginosa and S. aureus pneumonia in vivo. Coating of the tubes with sphingosine was stable, without obvious side effects on tracheal epithelial cells and did not induce inflammation. In summary, we describe a novel method to coat plastic surfaces and provide evidence for the application of sphingosine and phytosphingosine as novel antimicrobial coatings to prevent bacterial adherence and induce killing of pathogens on the surface of endotracheal tubes with potential to prevent biofilm formation and VAP.
\end{abstract}

\section{Key messages}

- Novel dip-coating method to coat plastic surfaces with lipids.

- Sphingosine and phytosphingosine as novel antimicrobial coatings on plastic surface.

- Sphingosine coatings of endotracheal tubes prevent bacterial adherence and biofilms.

- Sphingosine coatings of endotracheal tubes induce killing of pathogens.

- Sphingosine coatings of endotracheal tubes ventilator-associated pneumonia.

Keywords Coating · Plastic surfaces - Sphingosine - Ventilation - Acinetobacter baumannii Pseudomonas aeruginosa . Staphylococcus aureus

\section{Introduction}

Ventilator-associated pneumonia (VAP) is one of the most common nosocomial infections causing significant morbidity and

Aaron P. Seitz

seitzap@ucmail.uc.edu

Erich Gulbins

erich.gulbins@uni-due.de

1 Department of Surgery, College of Medicine, University of Cincinnati, 231 Albert Sabin Way ML 0558, Cincinnati, OH 45267, USA

2 Institute of Nutritional Science, Department of Toxicology, University of Potsdam, Arthur-Scheunert-Allee 114-116, 14558 Nuthetal, Germany mortality in critically ill patients. It affects up to $25 \%$ of mechanically ventilated patients and has an estimated mortality of $13 \%$ [1]. VAP adds 5-7 days to intensive care unit (ICU) length of stay and increases the length of hospitalization by 10-12 days [2].

3 Department of Molecular Biology, University Hospital Essen, University of Duisburg-Essen, Hufelandstrasse 55, 45122 Essen, Germany

4 Division of Research, Shriners Hospital for Children, Cincinnati, OH 45229, USA

5 Thoracic Transplantation, University Hospital Essen, University of Duisburg-Essen, Hufelandstrasse 55, 45122 Essen, Germany

6 Orthopedic Surgery, University Hospital Essen, University of Duisburg-Essen, Hufelandstrasse 55, 45122 Essen, Germany 
Evidence-based practices, which have been identified and implemented to reduce rates of VAP, include semi-recumbent positioning, daily wake-wean trials, small bowel tube feeding, prophylactic probiotics, and early tracheostomy $[1,3,4]$. Evidence has shown silver-coated endotracheal tubes to be effective at reducing rates of VAP by $36 \%[1,5]$. However, silver-coated tubes are not seen in routine hospital use. A potential reason for this lack of implementation is the large upfront cost of implementing silver-coated endotracheal tubes compared to standard plastic tubes.

Bacteria responsible for VAP are diverse, however, $60 \%$ of causative agents are gram-negative bacteria, most commonly $P$. aeruginosa and A. baumannii [6]. The most common gram-positive bacterium involved in VAP is $S$. aureus [6]. The cause of VAP is multifactorial but is undeniably related to the presence of the endotracheal tube. Tracheal intubation inhibits the cough reflex, affects mucociliary clearance, provides direct access for bacteria from the upper to the lower respiratory system, and allows for the formation of biofilm, which can subsequently be a source of persistent infection [7]. Biofilms are increasingly becoming an area of focus because of their important roles in chronic or persistent infections often resistant to standard antibiotic therapy [8]. Bacterial adhesion is the first step in biofilm formation [9] and thus, prevention of bacterial adherence on the surface of endotracheal tubes could have potential to significantly reduce rates of VAP. In addition, killing of bacteria embedded in biofilms is a major clinical problem and development of drugs that kill pathogens in biofilms would be of great clinical interest.

Sphingolipids are a group of lipids that modulate multiple cellular functions. Sphingosine is a sphingoid long chain base that is generated from ceramide by ceramidases. Sphingosine has been previously shown to have antimicrobial properties against both gram-positive and gram-negative bacteria [10]. It has been described as an integral part of the innate immunity of the skin [11], oral mucosa [12], epithelial cells of the trachea and the bronchi [13-15], and the gingiva [16]. Sphingosine is expressed at high concentrations in epithelial cells of the trachea and large bronchi of the lung and mediates an immediate killing of pathogens such as $P$. aeruginosa or $S$. aureus in vivo [13-15]. Patients or mice with cystic fibrosis suffer from reduced concentrations of sphingosine in the airways resulting in their high infection susceptibility [15].

In the present study, we established a novel coating method to obtain high concentrations of sphingosine on plastic surfaces. Sphingosine-coating prevented adherence and growth of planktonic or biofilm P. aeruginosa, S. aureus, and A. baumannii on the tubes in vitro and in vivo as well as the development of pneumonia via the ventilation tube in a mouse model. Sphingosine coating was stable and nontoxic against tracheal epithelial cells.
Fig. 1 Antimicrobial efficacy of sphingosine and phytosphingosinecoated endotracheal tubes. a Uncoated vs vehicle (hexane)-coated vs sphingosine-coated and b vehicle (acetone)-coated vs phytosphingosine-coated $1-\mathrm{cm}$ long segments of standard PVC endotracheal tubes were immersed for $12 \mathrm{~h}$ at $37^{\circ} \mathrm{C}$ in bacterial suspension containing $1000 \mathrm{CFU}$ of $A$. baumannii, P. aeruginosa, or methicillinresistant $S$. aureus (MRSA). Tube segments were then rinsed in $\mathrm{H} / \mathrm{S}$, sonicated to release adherent bacteria and bacterial counts (colony forming units, CFU) were determined. Hexane-coating did not significantly reduce bacterial adherence and growth on the plastic surface. Sphingosine-coated segments prevented $99.4 \%(p<0.005), 97 \%(\mathrm{p}<$ $0.005)$, and $97 \%(p=0.05)$ bacterial adherence of A. baumannii $(n=6)$, $P$. aeruginosa $(n=6)$, and MRSA $(n=3)$, respectively. Coating with sphingomyelin, C16 ceramide, sphingosine 1-phoshate, or phosphatidylcholine was without effect on bacterial adherence/growth ( $n=6$ each). b Phytosphingosine-coated segments prevented $99.0 \%$ ( $p=0.009), 90 \%$ $(p<0.005)$, and $99.4 \%(p<0.005)$ bacterial adherence of $A$. baumannii $(n=5)$, . aeruginosa $(n=5)$, and MRSA $(n=5)$, respectively. $\mathbf{c}$ Bacterial suspension containing $10,000 \mathrm{CFU}$ in growth media was pipetted onto plastic coverslips, covered with plastic film, and incubated for $24 \mathrm{~h}$ at $37^{\circ} \mathrm{C}$. Coverslips were rinsed with $\mathrm{H} / \mathrm{S}$, incubated for $12 \mathrm{~h}$, adherent bacteria were released from the surface via sonication, plated and counted after overnight growth. Phytosphingosine-coated coverslips prevented 96\% ( $p=0.02), 99 \%(p=0.006)$, and 93\% $(p<0.005)$ bacterial adherence of $A$. baumannii $(n=20)$, . aeruginosa $(n=15)$, and MRSA $(n=$ 20 ), respectively. d Bacterial suspension containing 10,000 CFU in growth media was pipetted onto plastic coverslips, covered with plastic film, and incubated for $24 \mathrm{~h}$. Additional suspensions of 10,000 CFU were pipetted onto the coverslips after $24 \mathrm{~h}$ and $48 \mathrm{~h}$. At $72 \mathrm{~h}, \mathrm{CFU}$ on the cover slips were determined. Phytosphingosine-coated coverslips prevented 93\% ( $p=0.005), 94 \%(p=0.005)$, and 99\% $(p=0.03)$ bacterial adherence and growth of A. baumannii $(n=3), P$. aeruginosa $(n=3)$, and MRSA $(n=3)$, respectively. e Small parts of the tubes were coated as indicated, $10^{4} \mathrm{CFU}$ of $P$. aeruginosa, A. baumannii or $S$. aureus were pipetted as a small drop onto the tube, incubated for $60 \mathrm{~min}, 500 \mu \mathrm{TSB}$ were added, and the bacteria were allowed to grow for $1 \mathrm{~h}$. Aliquots of the cultures were then plated and CFU were determined after growth o/n $(n=$ 6 each). Shown are mean $\pm \mathrm{SD}$, significant differences were compared to the respective control using ANOVA or $t$ test, $* p<0.05, * * p<0.01$, $* * * p<0.001$

\section{Results}

\section{Sphingosine prevents bacterial adherence and growth on endotracheal tubes}

Endotracheal tubes were coated with sphingosine and phytosphingosine in reagent grade hexane and acetone, respectively. Coating tube segments with solvent only did not significantly affect the adherence and growth of $P$. aeruginosa, A. baumannii, and methicillin-resistant $S$. aureus to the surface of the PVC compared to uncoated controls ( $p=0.78,0.63,0.73$, respectively), while sphingosine-coated and phytosphingosine-coated tube segments greatly reduced (more than 100 -fold) adherence and growth of $P$. aeruginosa, A. baumannii, and methicillin-resistant $S$. aureus (MRSA) to the plastic surface (Fig. 1a, b). Coating of tubes with other lipids such as sphingomyelin, ceramide, sphingosine 1-phosphate, and 


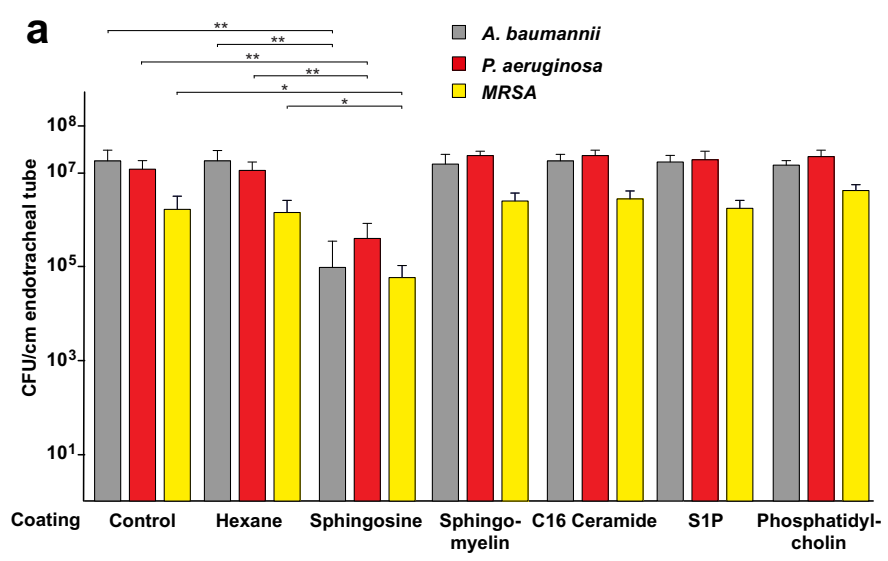

b

C

d
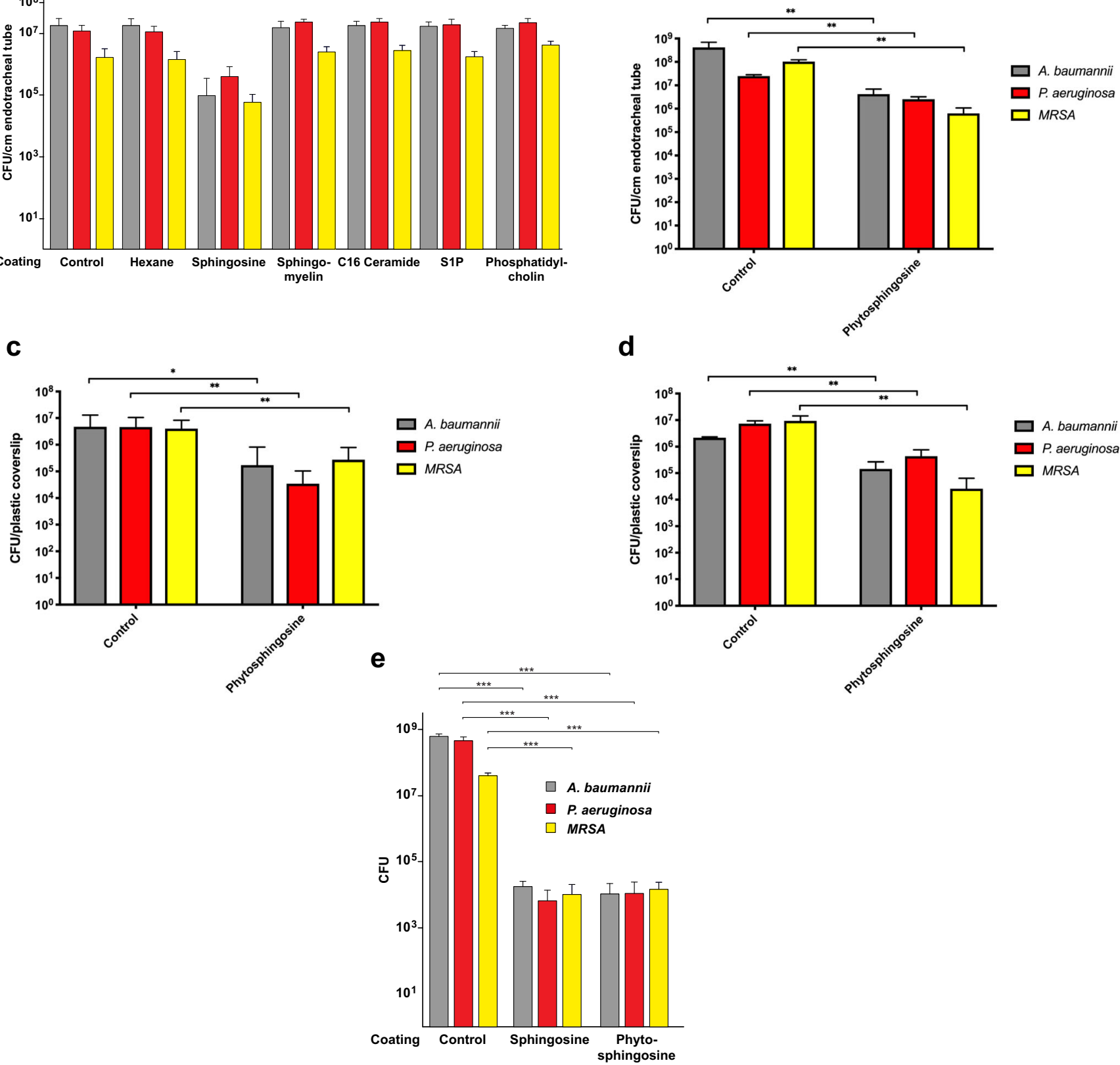

A. baumannii

$\square$ P. aeruginosa $\square$ MRSA

phosphatidylcholine (all $30 \mathrm{mM}$ ) did not result in killing of the pathogens (Fig. 1a). Coating was controlled by addition of radioactive compounds and extraction of the lipids from the surfaces (not shown).

Quantifying bacteria adherent to surfaces after 24-h incubation immersed in bacterial suspension reaching greater than $10^{7} \mathrm{CFU} / \mathrm{mL}$ as in the experiments shown in Fig. 1 is not the most clinically relevant model of biofilm formation on endotracheal tubes. Endotracheal tubes in vivo are inoculated with bacteria, which adhere to the surface prior to biofilm formation. The source of the bacterial inoculant (i.e., oral secretions, gastric reflux, inhaled droplets, etc.) has been reviewed multiple times [17]. Regardless of the mechanism, bacteria adherent to the surface of an endotracheal tube are likely subjected to an environment exposed to humidified air. Thus, to simulate this condition, we modified our antimicrobial assay. Since bacteria adherent to endotracheal tubes were difficult to image via microscopy secondary to the curved nature of the tube, we coated flat plastic coverslips as a surrogate for PVC endotracheal tubes.

The antimicrobial assay we used is a variation of the international standard, ISO 22196 Test for Antimicrobial Activity of Plastics. Briefly, 10,000 CFU of P. aeruginosa, 
A. baumannii, and methicillin-resistant $S$. aureus in $10 \mu \mathrm{L}$ TSB was placed on the coated coverslips, covered with a $2 \mathrm{~cm} \times 3 \mathrm{~cm}$ piece of low-density polyethylene plastic film, incubated at $37^{\circ} \mathrm{C}$ for $24 \mathrm{~h}$ and rinsed. In order to simulate the environment of an endotracheal tube in vivo, we then suspended the coverslips in air and incubated them at $37{ }^{\circ} \mathrm{C}$, with $100 \%$ humidity for $12 \mathrm{~h}$.

The results show that phytosphingosine reduced bacterial adherence and growth on the plastic surface by $93-99 \%$ compared to controls (Figs. 1c, d and 2). Similar results were obtained for sphingosine-coated surfaces.

In order to assess the durability of the sphingosine- and phytosphingosine-coating against bacteria, we performed the above protocol with the addition of a second and third inoculation of 10,000 CFU P. aeruginosa, A. baumannii, and methicillinresistant $S$. aureus in $10 \mu \mathrm{L}$ TSB at $24 \mathrm{~h}$ and $48 \mathrm{~h}$. After $72 \mathrm{~h}$, rinsing, dry incubation, and sonication were performed. As shown in Fig. 1d, we found the anti-adherent/anti-growth properties of phytosphingosine-coated plastic were durable at least up to $72 \mathrm{~h}$. Similar results were obtained for sphingosine.

Finally, we tested whether coating of plastic tubes with sphingosine or phytosphingosine also results in killing of the bacteria. To this end, small parts of the tubes were coated with sphingosine or phytosphingosine or left uncoated or were treated with $\mathrm{C}_{2} \mathrm{H}_{5} \mathrm{OH}$ only, placed into wells of a 24-well plate and $10^{4}$ CFU of $P$. aeruginosa, A. baumannii, or $S$. aureus were pipetted as a small drop onto the tube. The samples were incubated for $60 \mathrm{~min}$ in a humidified atmosphere, $500 \mu \mathrm{l} \mathrm{TSB}$ was added and the remaining bacteria were allowed to grow for $1 \mathrm{~h}$. Aliquots of the cultures were then plated. The results show that sphingosine or phytosphingosine coating killed $P$. aeruginosa, A. baumannii, or S. aureus on the surface of the plastic tubes. The data are presented in Fig. 1e.

\section{Sphingosine and phytosphingosine prevent biofilm colonization in vitro}

The above results were obtained using a version of the international standard using PVC coverslips. This helped with imaging the biofilms, however, we also wanted to replicate in vivo condition with endotracheal tube segments. To more closely replicate the in vivo conditions, endotracheal tube segments were challenged with $P$. aeruginosa, A. baumannii, and methicillinresistant $S$. aureus small volume suspensions pipetted directly on tube segments and incubated for $24 \mathrm{~h}$. Adherent bacteria were released from the surface and quantified. The results of these tests showed that both, sphingosine and phytosphingosine, almost completely prevented adherence and growth of $P$. aeruginosa, A. baumannii, and methicillin-resistant S. aureus (Fig. 3a). Silver coating was effective against $P$. aeruginosa but failed to exhibit sufficient effects against $A$. baumannii and methicillin-resistant S. aureus.

In addition, we grew $P$. aeruginosa strains 338,345 , and PAO-1 as biofilms, removed the biofilm from the well plate, and added these preformed biofilms to sphingosine- or ethanol-coated plastic tubes. The samples were incubated for
Fig. 2 Antimicrobial efficacy of phytosphingosine and sphingosine-coated plastic. Displayed are the in vitro bacterial adherence and growth of, $P$. aeruginosa $(\mathbf{a}, \mathbf{d}, \mathbf{g})$, methicillin-resistant $S$. aureus $(M R S A)(\mathbf{b}, \mathbf{e}, \mathbf{h})$, and A. baumannii $(\mathbf{c}, \mathbf{f}, \mathbf{i})$ to vehicle (ethanol)-treated $(\mathbf{a}, \mathbf{b}, \mathbf{c})$ compared to sphingosine-coated (d, e, f), and phytosphingosinecoated $(\mathbf{g}, \mathbf{h}, \mathbf{i})$ plastic coverslips. Plastic slides were fixed, stained with crystal violet, mounted on glass slides and bacteria were visualized by light microscopy $(63 \mathrm{x})$. Shown are typical results from a total of three experiments

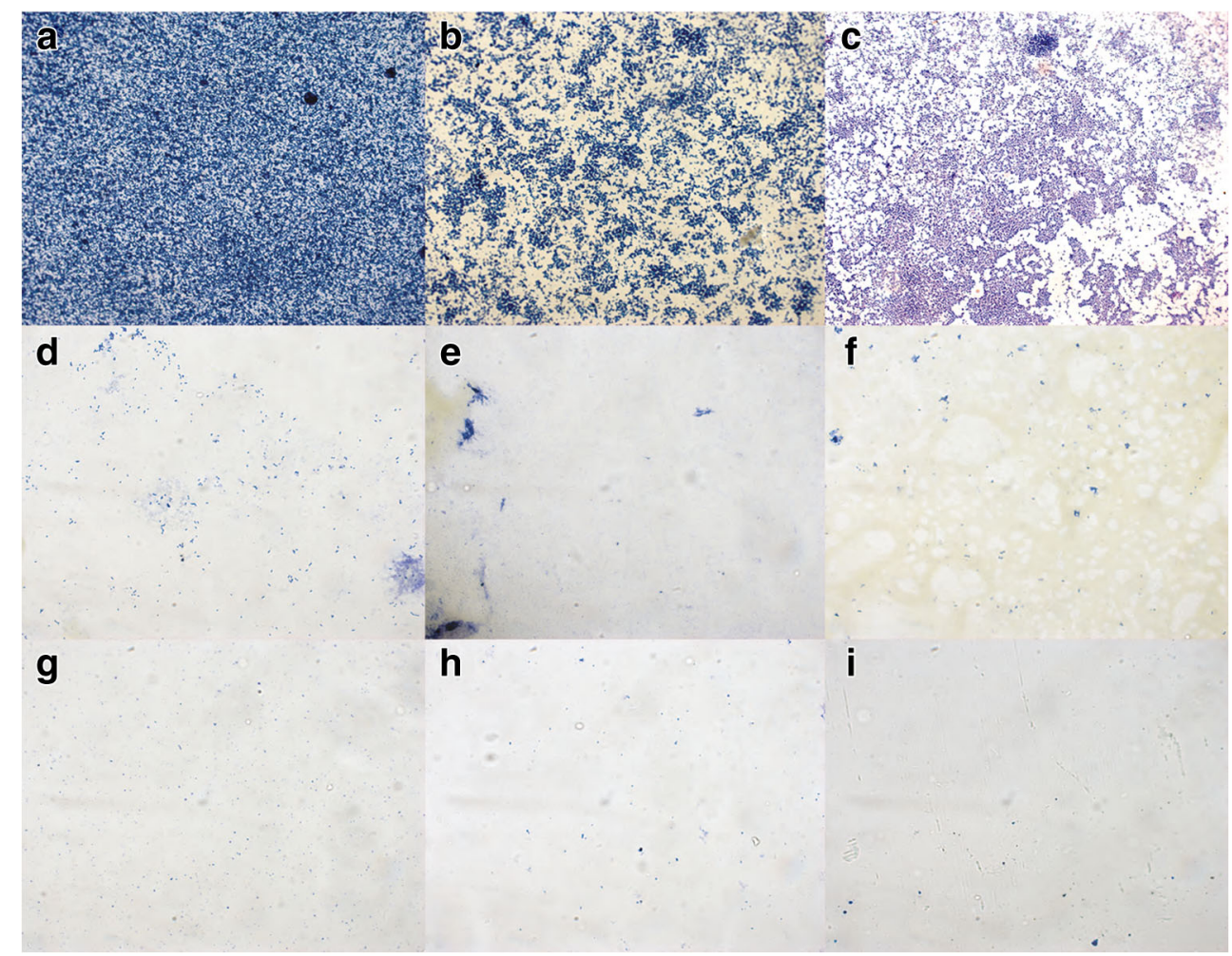



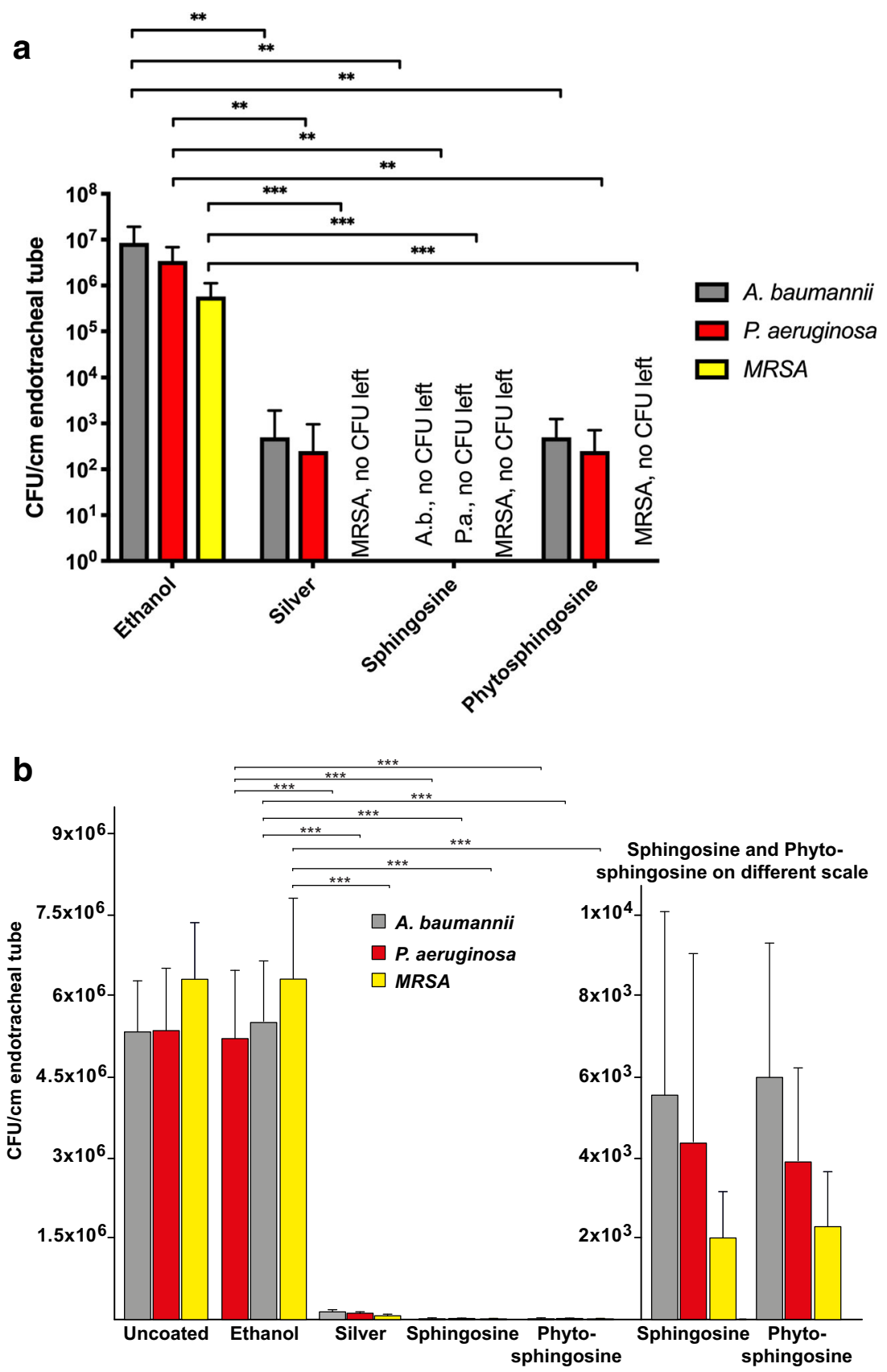

Fig. 3 Antimicrobial efficacy of silver-coated, sphingosine-coated, and phytosphingosine-coated endotracheal tubes. a Endotracheal tube segments were challenged by placing $10 \mu \mathrm{L}$ of bacterial suspensions in TSB onto the surface, incubated at $37^{\circ} \mathrm{C}$ for $24 \mathrm{~h}$, sonicated for $15 \mathrm{~min}$ to release adherent bacteria, and bacteria were plated and colonies were counted after overnight growth. Shown is the in vitro bacterial adherence and growth of $A$. baumannii, $P$. aeruginosa, and methicillin-resistant S. aureus (MRSA) to vehicle (ethanol)-treated, commercially available silver-coated, sphingosine-coated, and phytosphingosine-coated segments of 8.0 standard polyvinyl chloride endotracheal tubes. Silvercoated segments provided a 4.1, 3.8, and $6.5 \log$ reduction against bacterial adherence of $P$. aeruginosa, A. baumannii, and MRSA, respectively, compared to ethanol-coated controls. Sphingosine-coated segments

$60 \mathrm{~min}$; tubes were washed; bacteria were released, plated, grown overnight; and colonies were counted. The results provided a $6.5 \mathrm{log}$ reduction against all three strains and phytosphingosine-coated segments provided a 4.1, 3.8, and $6.5 \log$ reduction against $P$. aeruginosa, A. baumannii, and MRSA, respectively, compared to ethanol-coated controls. Shown are mean \pm SD, ANOVA, $* p<0.05, * * p<0.01, * * * p<0.001$. b $P$. aeruginosa strains 338,345 , and 762 were grown in biofilms, the biofilm containing the bacteria was removed from the plate and pipetted onto sphingosine-coated, phytosphingosine-coated, silver-coated, ethanol-only treated or uncoated/untreated plastic tubes, incubated for $60 \mathrm{~min}$, bacteria were released, and the number of bacteria on the tube was determined by plating and overnight growth. Shown is the mean $\pm \mathrm{SD}, n=6$ each, ANOVA, $* p<0.05, * * p<0.01, * * * p<0.001$. The right panel shows the values for sphingosine and phytosphingosine on a different scale bar

reveal that sphingosine-coating prevented the growth of bacteria within biofilms on the surface of plastic tubes (Fig. 3b). 
In summary, these data indicate that plastic surfaces coated with sphingosine and phytosphingosine provide very high protection against infection with $P$. aeruginosa, A. baumannii, and MRSA, even under very stringent test conditions.

\section{Characterization of sphingosine and phytosphingosine-coated endotracheal tubes}

Sphingosine and phytosphingosine are molecules found on various biological membranes of living organisms. They are also classified as nonionic biosurfactants. Adsorption of surfactants onto solid surfaces in aqueous solutions is a well-studied process. Multiple mathematical models have been developed to characterize this process (i.e., Langmuir isotherms) [18]. These models describe a process by which a monolayer (or bilayer) of surfactant molecules adsorb onto solid surfaces. Any attempt at increasing the aqueous concentration of the surfactant in order to increase the adsorption is limited by the critical micelle concentration of the surfactant [18]. Our method of molecular crystal thin film formation is not limited by the same parameters. As shown in Fig. $4 \mathrm{a}-\mathrm{f}$, our coating method results in adsorption of 3-dimensional surfactant structures with features as large as $20 \mu \mathrm{m}$ in diameter. These three-dimensional structures, while not as organized as mono- or bilayer films, contain large amounts of adsorbed antimicrobial biosurfactant, i.e., sphingosine and phytosphingosine, while still $<10 \mu \mathrm{m}$ in thickness.

\section{Quantification of sphingosine}

To determine the total amount of sphingosine present on the surface of the endotracheal tubes after dip coating, we performed mass spectrometry (Fig. 4g) and a sphingosine kinase assay (Fig. 4g). Both methods confirmed a concentration of sphingosine in the nmol range per $\mathrm{cm}^{2}$. This is an impressive amount as sphingosine has been shown to kill bacteria in solution with concentrations of $\mathrm{nmol} / \mathrm{L}$ to $\mu \mathrm{mol} / \mathrm{L}$ [13].

\section{Durability of sphingosine coating}

Any antimicrobial coating applied to endotracheal tubes (or any medical device) must have stability and durability when immersed in biological fluids. We studied the durability of sphingosine coating in blood and saliva for 7 days quantified by sphingosine kinase assay and in water, H/S, and PBS imaged with electron microscopy. As shown in Fig. 4g, sphingosine coating was stable in saliva, but not in blood. The amount of sphingosine quantified after soaking in saliva was nearly double of control. This indicates that sphingosine present in the saliva was adherent to the previously sphingosine-coated endotracheal tube pieces. Next, we tested whether a 7-day incubation of plastic intubation tubes with saliva affects killing/biofilm formation of with $P$. aeruginosa, A. baumannii, or S. aureus on the tube's surface. To this end, plastic tubes were coated with sphingosine, incubated for 7 days in saliva, washed in $\mathrm{H}_{2} \mathrm{O}$, and incubated with $P$. aeruginosa, A. baumanni, or $S$. aureus. As control, we used tubes that were also coated, but simply stored for 7 days. The results show that the coated tubes still killed the bacteria and incubation in saliva did not affect the potency of sphingosine coating to kill the bacteria (Fig. $4 \mathrm{~g}$ ).

Measuring the amount of sphingosine on the tubes also allowed us to test whether the sonication, which was used to release bacteria from the plastic surface, has an impact on killing. Sonication may release variable amounts of sphingosine into the buffer, which might be still active and kill released bacteria. To exclude killing of bacteria by released sphingosine, we neutralized sphingosine prior to sonication. Sphingosine binds to proteins, which neutralizes the antibacterial effects of sphingosine, and we therefore used a medium containing a high concentration of BSA (lipid-free; $100 \mathrm{~g} / \mathrm{L})$. In addition, we added sphingosine kinase $1(10 \mu \mathrm{g}$ with a specific activity of $2500 \mathrm{pmol} / \mathrm{min} / \mu \mathrm{g}$, i.e., $25 \mathrm{nmoles}$ sphingosine/min are consumed), which converts sphingosine into sphingosine 1-phosphate, which does not kill bacteria (ref. 13 and Fig. 1a). We used $1 \mathrm{~cm}^{2}$ plastic in these experiments binding approximately 150 nmoles sphingosines (please see Fig. 4g). To ensure complete conversion of any sphingosine to sphingosine 1-phosphate and/or binding to $\mathrm{BSA}$, we incubated the plastic pieces for $30 \mathrm{~min}$ with this solution, then sonicated and determined the bacterial numbers as above. The CFU obtained in these experiments were controls (no coating, no treatments): P. aeruginosa: $(4.9 \pm 0.90) \times$ $10^{6} \mathrm{CFU}$; A. baumannii: $(4.8 \pm 0.88) \times 10^{6} \mathrm{CFU}$; S. aureus: $(4.2 \pm 0.74) \times 10^{6} \mathrm{CFU}$; coating with sphingosine + BSA and sphingosine kinase treatment: $P$. aeruginosa: $(1.03 \pm 0.94) \times$ $10^{3} \mathrm{CFU}$; A. baumannii: $(1.51 \pm 1.02) \times 10^{3} \mathrm{CFU}$; $S$. aureus: $(1.83 \pm 1.03) \times 10^{3}$ CFU. The numbers did not significantly differ from those obtained without BSA and sphingosine kinase reported in Fig. 1c, indicating that killing of the bacteria/ prevention of biofilm formation occurred prior to the release of the bacteria from the plastic.

Controls confirmed that addition of BSA plus sphingosine kinase to a solution of containing 150 nmoles sphingosine at a concentration of $150 \mu \mathrm{M}$ sphingosine followed by inoculation with $P$. aeruginosa, S. aureus, and A. baumannii completely prevents killing of the bacteria, while a concentration of $150 \mu \mathrm{M}$ sphingosine is sufficient to induce a $100 \%$ death of all bacteria (not shown).

The studies above establish a novel coating technique and demonstrate that coating of endotracheal tubes with sphingosine and phytosphingosine results in stable coatings of the 
plastic surfaces. The coated tubes prevent infection with $P$. aeruginosa, A. baumannii and methicillin-resistant $S$. aureus. However, these data are all in vitro. Therefore, we investigated whether coating of endotracheal/plastic tubes with sphingosine prevents bacterial pneumonia in vivo. We also determined the stability and potential toxicity of the coating in vivo.

\section{Sphingosine coating prevents $P$. aeruginosa and $S$. aureus pneumonia in vivo}

VAP is a major clinical problem. To test whether coating of endotracheal tubes with sphingosine is able to prevent infections with $P$. aeruginosa and $S$. aureus via endotracheal tubes,

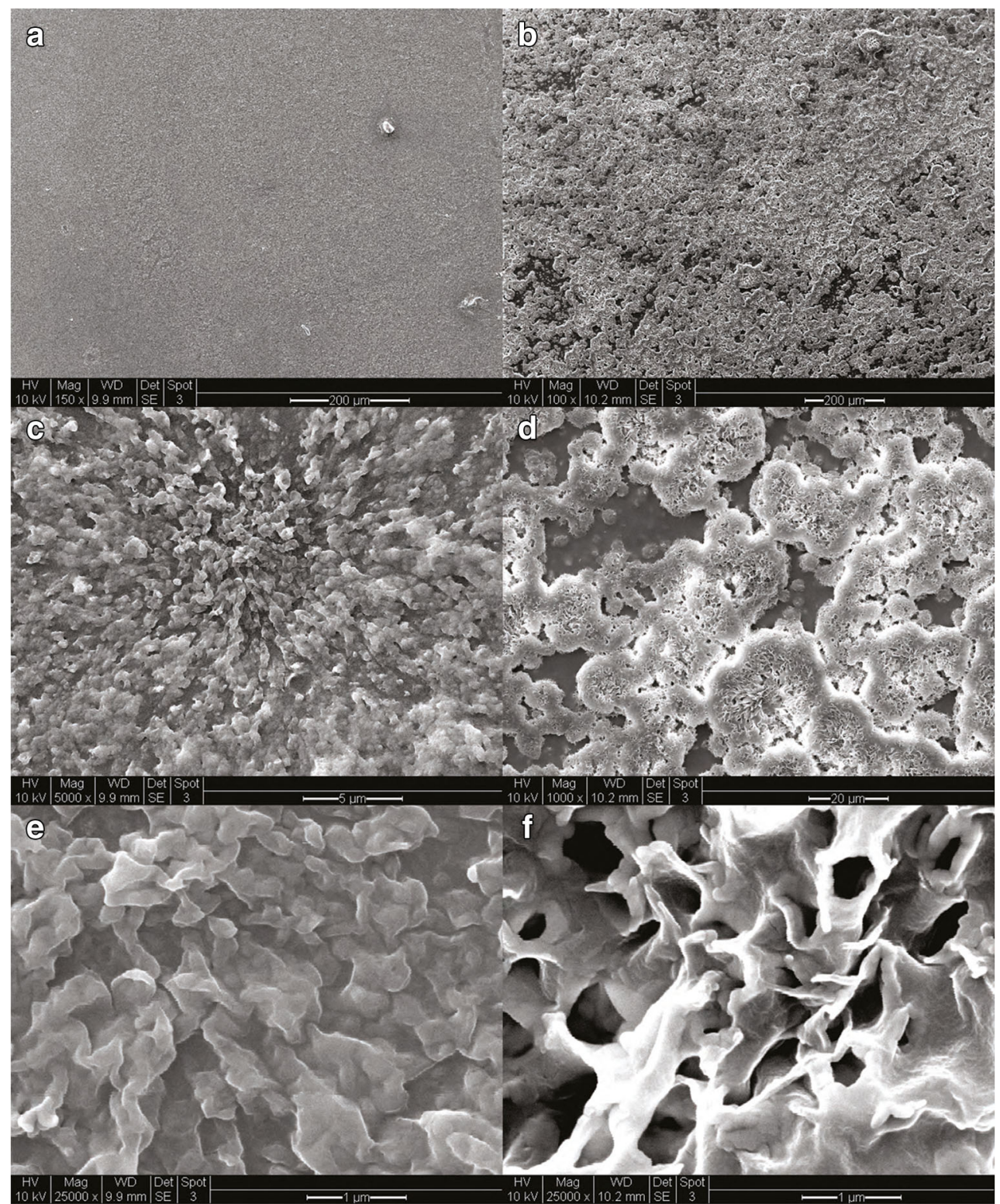

Fig. 4 Morphology and quantity and durability of sphingosine/ phytosphingosine coatings. $1 \mathrm{~cm}$ segments of endotracheal tubes were dip-coated once in a, c, e $30 \mathrm{mM}$ sphingosine or b, d, f $30 \mathrm{mM}$ phytosphingosine in $100 \%$ ethanol heated to $70{ }^{\circ} \mathrm{C}$. Segments were then stained with $0.1 \%$ osmium tetroxide, sputter-coated with gold/platinum, and imaged with scanning electron microscopy. Images were obtained at different magnifications as indicated. Shown are representative figures from three independent studies. $\mathrm{g}$ Left panel: Endotracheal tube segments were dip coated in $30 \mathrm{mM}$ sphingosine solution. Sphingosine was extracted and analyzed by mass spectrometry or measured by a sphingosine kinase assay on the tube. The sphingosine-coated endotracheal tube segments were also immersed in saliva or blood and incubated at $37^{\circ} \mathrm{C}$ for 7 days prior to the sphingosine kinase assay. Right panel: Incubation of tube segments after the 7 day incubation in saliva with P. aeruginosa, A. baumannii, or $S$. aureus still kills the bacteria to a similar degree as without incubation of the coated tube with saliva. Experiments were performed as described in Fig. 1. Shown is the mean \pm SD of the sphingosine concentration, $n=3$ each or $n=6$ for all infection experiments 


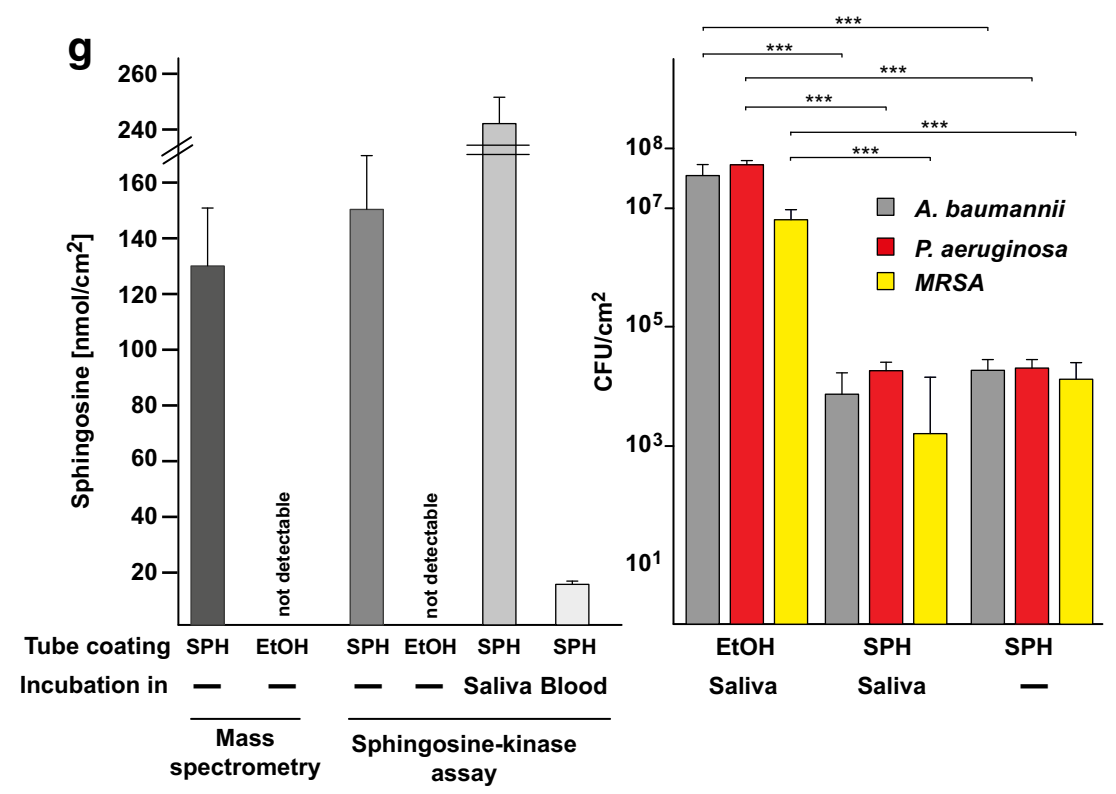

Fig. 4 (continued)

we coated tubes with sphingosine in hexane or ethanol, or only with hexane or ethanol or left them uncoated. We used sphingosine in these experiments because it is normally present in eukaryotic cells and therefore will not result in an antigenic stimulation of lymphocytes. We then intubated mice into the trachea with these plastic tubes and infected the tube with $5 \times 10^{5} \mathrm{CFU}$ in $2 \mu \mathrm{H} / \mathrm{S}$ applied at the outlet of the tube, approximately $5 \mathrm{~mm}$ proximal to the insertion site of the tube at the trachea. Mice were sacrificed $45 \mathrm{~min}$ after the infection; the lungs were removed, homogenized, and bacterial CFU were determined after overnight growth on LB plates. Mice intubated with uncoated or solvent only coated tubes developed severe pneumonia (Fig. 5a, b), while mice intubated with sphingosine-coated tubes were protected. Sphingosine coating completely protected the mice from pneumonia after infection with the $P$. aeruginosa strains 338 and 345 and a multi-resistant, clinical $S$. aureus isolate, and reduced the bacterial CFU in the lung or on the tubes by more than $98 \%$, even after infection with the very aggressive and highly motile clinical P. aeruginosa strain 762 (19) (Fig. 5a, b). No difference was noted between sphingosine-coating with hexane or ethanol as solvent (not shown).

\section{Sphingosine coating of endotracheal tubes is stable in vivo}

To test the stability of sphingosine after coating on endotracheal tubes in vivo, we inserted a tube over a total of $4 \mathrm{~h}$ into mice. To avoid variations due to prolonged and very deep anesthesia, we intubated 4 mice consecutively on 4 days for $1 \mathrm{~h}$ each. We then determined the concentration of sphingosine on the outer and inner surface of the tube by a sphingosine-kinase assay. Ethanolonly coated and uncoated tubes that were also employed for intubation and sphingosine-coated tubes that were not used for intubation served as controls. To discriminate between sphingosine that is directly bound to the plastic and sphingosine that might have been released and binds within mucus that sticks to the tube, we measured sphingosine on the tubes with or without washing in H/S. The results show that the concentration of sphingosine on tubes did not significantly decrease with intubation (Fig. 6a). Washing the tubes in $\mathrm{H} / \mathrm{S}$ slightly reduced the sphingosine amount on the tube. The ethanol-only coated tubes also contained some sphingosine on the surface after intubation, but much less than the sphingosinecoated tubes (Fig. 6a). Thus, the tubes very likely bind mucus and thereby sphingosine is present in the mucus of the airways. Very similar results were obtained for coating tubes in sphingosine in hexane or hexane as control (not shown).

\section{Sphingosine released from the intubation tube accumulates in the mucus of the trachea}

Next, we investigated how much sphingosine is transferred from the tube into the trachea and, in particular, onto the surface of the tracheal epithelial cells. To this end, we intubated the mice for $60 \mathrm{~min}$ with sphingosine or ethanol-only coated tubes, removed the tube, and determined the concentration of sphingosine in the total trachea by mass spectrometry. These experiments revealed a marked increase of sphingosine in the trachea compared to the levels in mice intubated with control tubes (Fig. 6b), although this amount is still only a very minor 

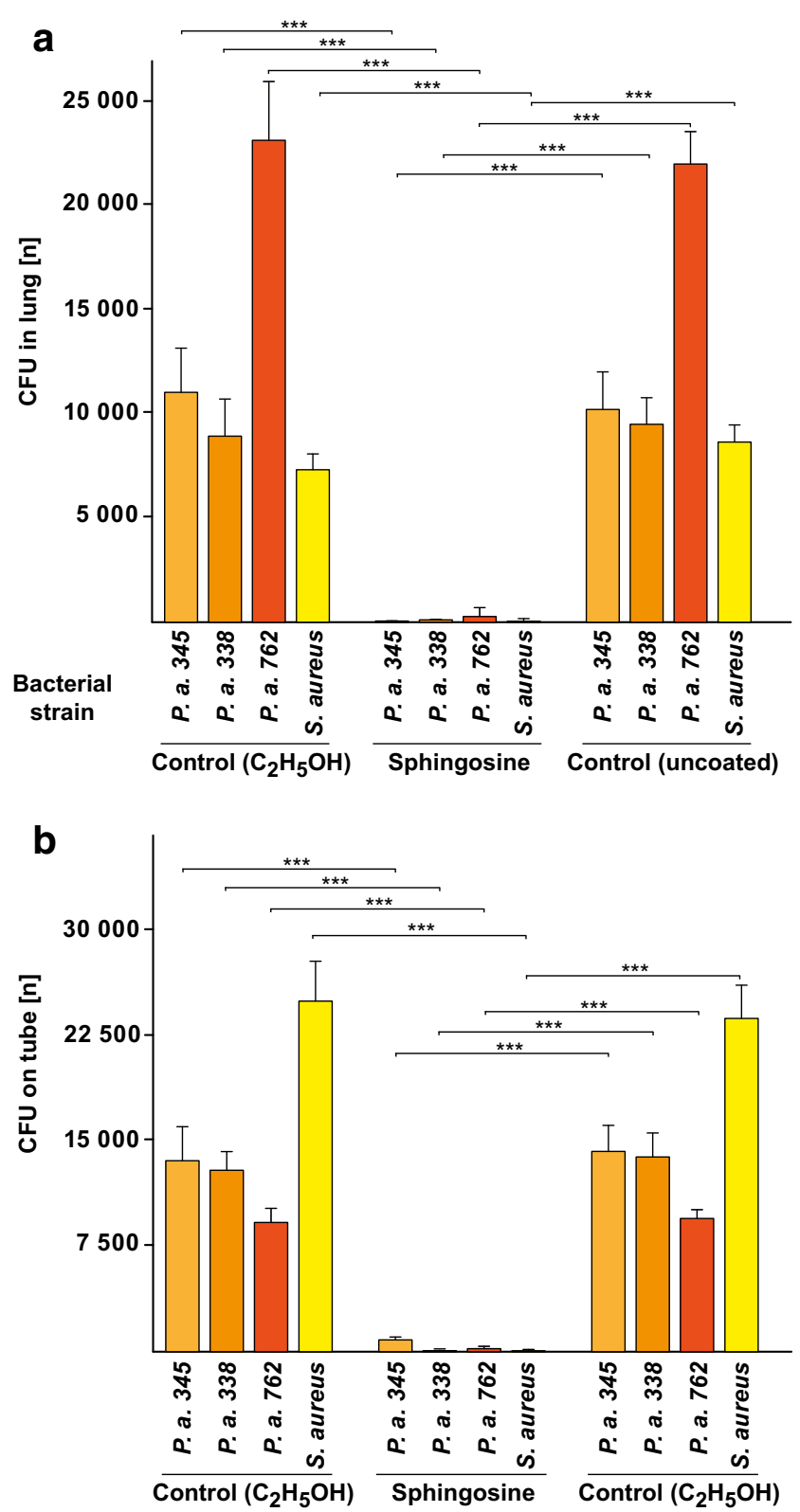

Fig. 5 Sphingosine-coating of ventilation tubes prevents $P$. aeruginosa and $S$. aureus pneumonia. Mice were intubated, infected at the proximal outlet of the ventilation tube with $5 \times 10^{5}$ CFU P. aeruginosa $(P . a$.) or a multi-resistant, clinical isolate of $S$. aureus in $2 \mu \mathrm{L} \mathrm{H} / \mathrm{S}$, the lungs were removed after $45 \mathrm{~min}$ and bacterial counts in the a lung and on the $\mathbf{b}$ tube were determined. Coating of the tubes with sphingosine prevented the infections. Mice were infected with three different $P$. aeruginosa strains, i.e., 338,345 , and 762 , as well as a multi-resistant, clinical isolate of $S$. aureus. Ethanol-coating of the tube was without effect on bacterial infection. Shown is the mean $\pm \mathrm{SD}$ of bacterial CFU in the a lung and the number of the bacteria on the $\mathbf{b}$ tube, $n=6$ each, ANOVA, $* * *$ $p<0.001$

fraction of the tube-bound sphingosine. To determine the topology of sphingosine accumulation after intubation with sphingosine-coated tubes, we performed stainings of trachea from mice that were intubated with sphingosine- or controlcoated tubes for $60 \mathrm{~min}$, with anti-sphingosine antibodies.
Surprisingly, the results did not reveal a significant accumulation of sphingosine in tracheal epithelial or any other cell of the trachea (Fig. 6c). This finding suggests that sphingosine released from the tubes accumulates in the mucus on top of the epithelial cells. This mucus is washed off during the fixation of the trachea and, thus, any sphingosine within the mucus would be removed. To test this hypothesis, we performed in situ surface sphingosine kinase assay and determined the concentration of sphingosine on the surface of trachea that was subjected to a surface kinase assay after intubation and removal of the trachea followed by extensive washing in $\mathrm{H} / \mathrm{S}$ prior to the kinase assay or immediate kinase assay without any washing. In addition, we also measured the amount of sphingosine in the wash solution. The results reveal an increase of sphingosine on the surface of unwashed trachea, immediately subjected to surface sphingosine kinase assays after intubation (Fig. 6d). Washing of the trachea abrogated the increase of sphingosine on the surface of the trachea after intubation with sphingosine-coated tubes (Fig. 6d). Sphingosine was recovered in the wash solution (Fig. 6d). This indicates that sphingosine released from the surface of the intubation tube remained in the mucus on the tracheal epithelial cells. The total amount of sphingosine on the tube inserted in the trachea was $29.1 \pm 1.8 \mathrm{nmol}$ (Fig. 6a shows values normalized to $1 \mathrm{~cm}^{2}$, the surface of the inserted tube is approximately $\left.0.25 \mathrm{~cm}^{2}\right)$. Thus, approximately only $1 \%(\sim 300 \mathrm{pmol})$ of the total sphingosine bound to the tube was released into the mucus.

\section{Sphingosine coating of endotracheal tubes is not toxic or pro-inflammatory in vivo}

To exclude toxic or pro-inflammatory effects of sphingosinecoated tubes, we intubated mice for $2 \mathrm{~h}$ with sphingosinecoated tubes or the appropriate controls, removed the trachea, fixed the trachea in PFA, and performed H\&E, Cy3-coupled anti-Gr1-antibody, and TUNEL stainings of paraffin sections. We did not observe any structural damage, influx of granulocytes/monocytes, or induction of cell death in the trachea of mice intubated with sphingosine-coated plastic tubes (Fig. 6e-g).

\section{Discussion}

Our data show that sphingosine- and phytosphingosine-coated endotracheal tubes are highly efficacious at preventing bacterial adherence and growth against three of the most common pathogens, $P$. aeruginosa, A. baumannii, and $S$. aureus, associated with VAP when compared with standard plasticized PVC endotracheal tubes under a variety of conditions. Additionally, we have shown that the sphingolipid molecular crystal thin film coating is effective, stable, and nontoxic 


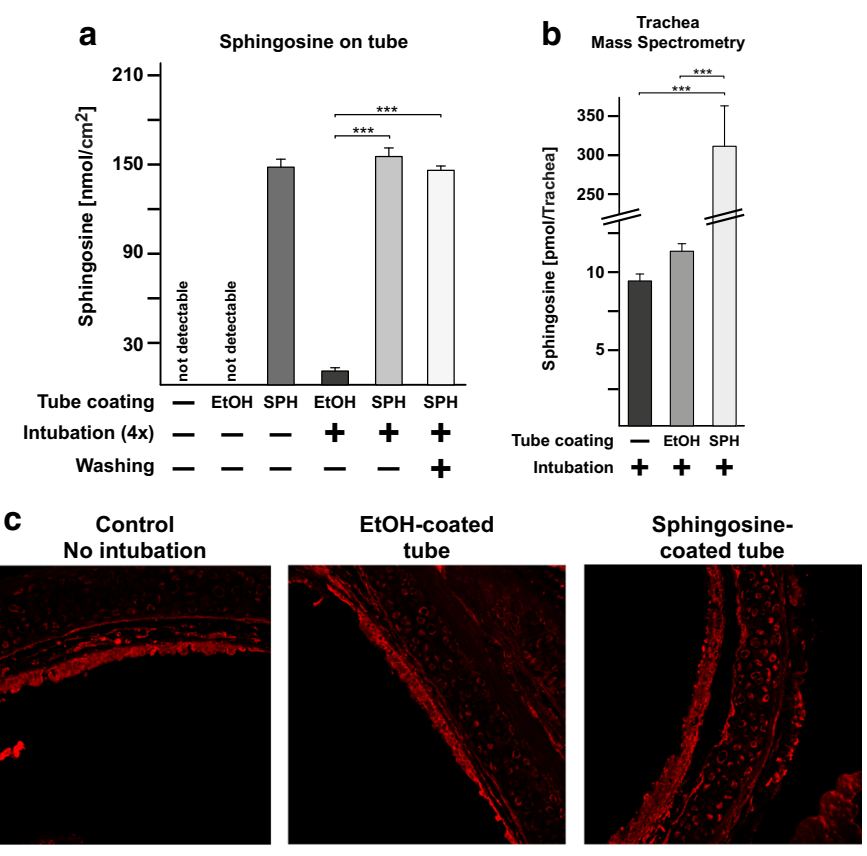

Staining: Cy3-anti-Sphingosine-antibodies
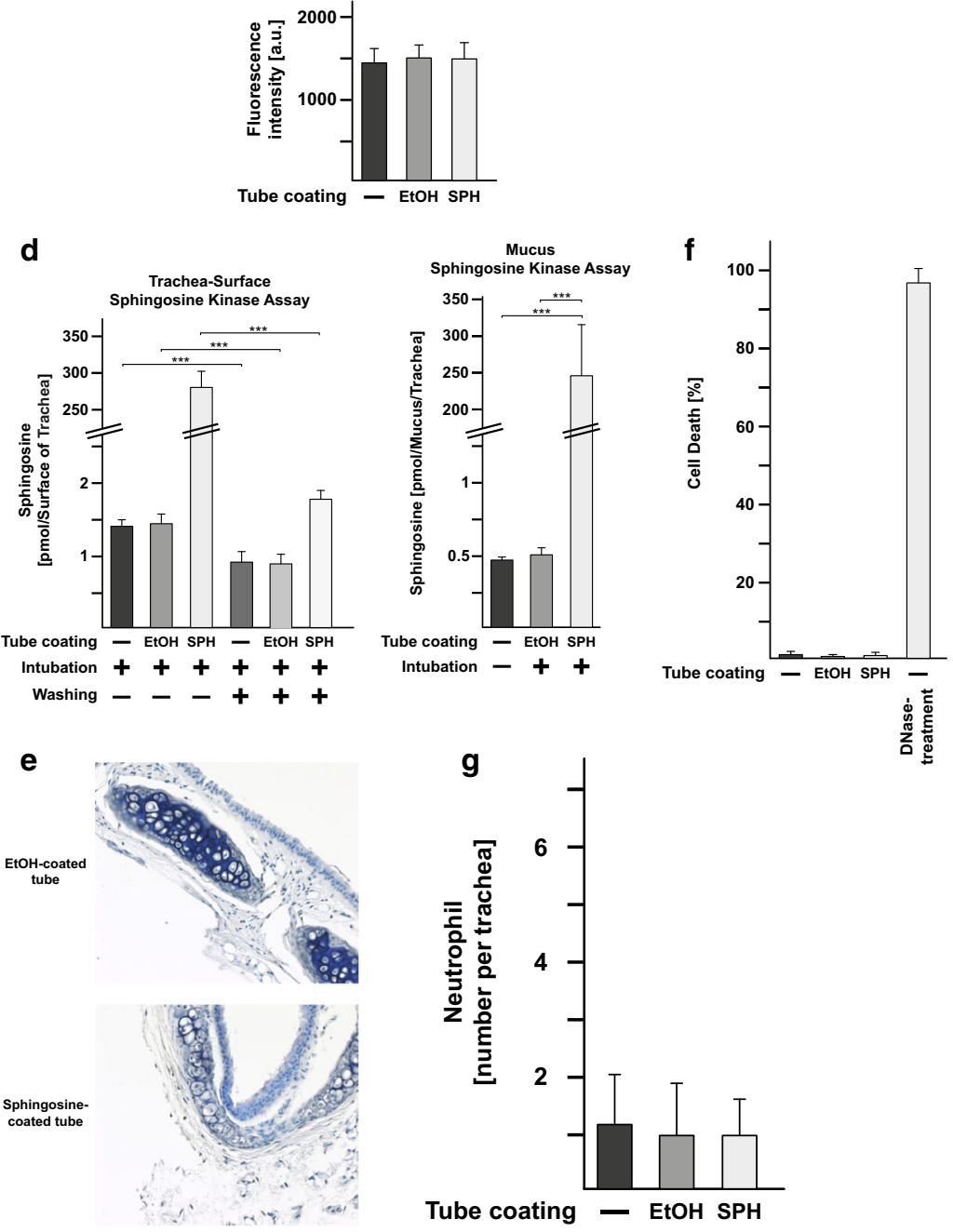
Fig. 6 Sphingosine coating of endotracheal tubes is stable in vivo, nontoxic to tracheal epithelial cells, and does not induce inflammation. a Tubes were sphingosine ( $\mathrm{SPH})$ or ethanol (EtOH)-coated and inserted over a total of $4 \mathrm{~h}$ into mice. To avoid variations due to prolonged and very deep anesthesia, we intubated 4 mice consecutively on 4 days for $1 \mathrm{~h}$ each. The concentration of sphingosine on the tube was determined by a sphingosine-kinase assay. Sphingosine concentrations on the tubes remained stable and even slightly increased, very likely by binding sphingosine-containing mucus, which is removed by washing the tube. Likewise, ethanol-coated tubes contained low amounts of sphingosine on the surface after intubation. Ethanol-coated or uncoated tubes (not used for intubation) were negative. Shown are the mean \pm SD of sphingosine concentrations in $\mathrm{pmol} / \mathrm{cm}^{2}, n=6$ each, ANOVA, $* p<0.05, * * p<0.01$, $* * * p<0.001$. b Mass spectrometry reveals that intubation of sphingosine-coated tubes results in a marked increase of total sphingosine in the trachea. Mice were intubated as above for $60 \mathrm{~min}$, the tube removed, the trachea removed and subjected to mass spectrometry. Shown is the mean of the concentration of sphingosine $\pm \mathrm{SD}, n=3-5$ each, ANOVA, *p<0.05, **p<0.01, ***p<0.001. c Immunofluorescence microscopy analysis of paraffin sections of trachea stained with Cy3-coupled anti-sphingosine antibodies does not reveal an increase of sphingosine in the epithelial cells of the trachea or the submucosa or any other cell of the trachea. Shown are typical results and the mean \pm SD of the quantification of the fluorescence staining of each 100 cells of the trachea from 6 independent samples per group. The fluorescence intensity is given in arbitrary units. d In situ surface sphingosinekinase assays on trachea from intubated mice reveal that most of the sphingosine released from the tube remains in the mucus of the trachea. Washing the trachea prior to the kinase assay removes the increase of sphingosine detected after intubation, which is recovered in the mucus in the wash buffer. Shown is the mean of the concentration of sphingosine $\pm \mathrm{SD}$ per trachea, $n=6$ each, ANOVA, $* p<0.05$, $* * p<0.01$, $* * * p<0.001$. To exclude toxic or pro-inflammatory effects of sphingosine-coated tubes, we performed hemalaun, Cy3-coupled antiGrl-antibody and TUNEL stainings of paraffin sections of the trachea from mice that were intubated with sphingosine- or ethanol (EtOH)-coated ventilation tubes. We did not observe any e structural damage, $\mathbf{f}$ induction of cell death, or $\mathbf{g}$ influx of granulocytes/monocytes into the submucosa epithelial cell layer in the trachea of mice intubated with sphingosine-coated plastic tubes. Displayed are typical examples of the stainings and the quantitative analysis of the number of dead epithelial cells and the influx of leukocytes, which were quantified in 10 sections from each trachea from 6 mice, i.e., a total of 60 sections. In each section, the entire epithelial cell layer and the submucosa of the trachea were investigated. Structural damage was determined as the number of disruptions of the epithelial cell layer. Shown are the mean $\pm \mathrm{SD}, n=6$ each, ANOVA, $* p<0.05, * * p<0.01, * * * p<0.001$

in vivo. Although only a small portion of coated sphingosine is released from the tubes, the absolute amount of sphingosine is approximately 300 pmoles. However, our studies demonstrate that most of the released sphingosine remains in the mucus on top of the epithelial cells of the trachea and only a small portion is incorporated into the epithelial cells. In accordance, tracheal epithelial cells from intubated mice do not show any signs of cell death and no influx of leukocytes into the trachea mucosa was observed, consistent with findings of our group that repeated inhalations of high concentrations of sphingosine, i.e., up to $1 \mathrm{mM}$ on 10 separate treatments over 11 days, had no evidence of toxicity [20]. The observation that some sphingosine is slowly released from the surface of the tubes into the mucus also implies that such an intubation may even improve the bactericidal effects of airway mucus and, thus, contribute to the protection from a VAP.

VAP continues to be a major cause of morbidity and mortality in critically ill patients. While prompt diagnosis and effective treatment with standard antibiotic regimens are important in mitigating the detrimental effects of VAP, development and implementation of more effective prevention strategies will decrease the incidence and likely provide a greater reduction in morbidity and mortality. Semi-recumbent positioning, chlorhexidine oral care, and subglottic suctioning have all been shown to reduce rates of VAP [21]. Silvercoated endotracheal tubes have also been shown to reduce rates of VAP [5, 22], but have not received widespread implementation. Silver coating provides clear protection against bacteria, however, coating with sphingosine provides similar or better protection against $P$. aeruginosa, $S$. aureus, and A. baumannii and even improves the natural defense systems of the mucociliary system in the upper airways.

The cause of VAP is multifactorial, but the presence of a biofilm that develops after only $24 \mathrm{~h}$ of tracheal intubation has been identified as a likely source of infection [23, 24]. The coating of plastic with sphingosine provides the advantage to prevent adherence of the bacteria and to kill the pathogens and, thus, has the potential to affect meaningful change in the prevention of VAP. Our in vivo experiments are only done for a total of $4 \mathrm{~h}$ because it is very difficult to perform longterm intubation experiments on mice. However, since the bacteria are killed already within the 45-min intubation period, we assume that a similarly fast killing occurs in longer time courses. In addition, sphingosine-coating on the tubes could be periodically restored by applying sphingosine by ventilation of sphingosine via the tube. Thus, sphingosine-coated tubes are very likely and also suitable in longer time courses.

We have discovered an interesting novel method that could be applied to other bioactive molecules and other surfaces in the formation of molecular crystal films. Our coating process utilizes an evaporation-induced molecular crystallization process that leaves a thin film of SPH.

At present, it is unknown how sphingosine kills bacteria. It is known that micellar sphingosine kills many pathogens including E. coli, P. aeruginosa, S. aureus, A. baumannii, Moraxella catarrhalis, Haemophilus influenzae, Burkholderia cepacia, Neisseria meningitides, and Neisseria gonorrhoeae $[10-15,25]$. It is possible that sphingosine simply kills pathogens by its biophysical properties, which would also suggest that sphingosine's antimicrobial mechanism is not prone to development of bacterial resistance. On the other hand, bacteria express sphingosine-responsive elements [26], suggesting that sphingosine may also have some biochemical effects in bacteria.

In summary, sphingosine and phytosphingosine-coating effectively prevent adherence of $P$. aeruginosa, $S$. aureus, and A. baumannii to the surface of endotracheal tubes with an 
effectiveness comparable to silver-coating. Sphingosine coating on endotracheal tubes prevents $P$. aeruginos $a$ and $S$. aureus infection over endotracheal tubes, is stable over time, and is safe in vivo. In vitro, sphingosine and phytosphingosine were shown to have antimicrobial durability of at least 4 days and a coating durability in aqueous solutions and saliva of at least 7 days. Future large animal studies are necessary to establish the safety of sphingolipid coatings and future randomized clinical trials will be necessary to determine sphingosine's or phytosphingosine's ability to provide a cost-effective preventative strategy to reduce rates of VAP.

\section{Conclusions}

We describe a novel method to coat plastic surfaces and provide evidence for the application of sphingosine and phytosphingosine as novel antimicrobial coatings to prevent bacterial adherence and induce killing of pathogens on the surface of endotracheal tubes with potential to prevent biofilm formation and ventilator-associated pneumonia.

\section{Materials and methods}

\section{Animal procedures}

The study protocol was reviewed and approved by the University of Cincinnati Institutional Animal Care and Use Committee (IACUC) and USAF Surgeon General Office of Research Oversight \& Compliance. Animals were handled and studies were conducted under a program of animal care accredited by the Association for Assessment and Accreditation of Laboratory Animal Care International (AAALAC) and in accordance with the "Guide for the Care and Use of Laboratory Animals" (NRC, 2011; in compliance with DoDI 3216.1).

\section{Materials}

D-erythrosphingosine (d18:1), D-ribo-phytosphingosine, C16 ceramide, sphingomyelin, and sphingosine 1-phosphate (S1P) were purchased from Avanti Polar Lipids (Alabaster, AL), phosphatidylcholine from Sigma (Deisenhofen, Germany). Anhydrous hexane and acetone were purchased from SigmaAldrich (St. Louis, MO). $\left[{ }^{3} \mathrm{H}\right]$ - or $\left[{ }^{14} \mathrm{C}\right]$-labeled sphingomyelin, $\mathrm{C} 16$ ceramide, and phosphatidylcholine were from Perkin Elmer, $\left[{ }^{3} \mathrm{H}\right] \mathrm{S} 1 \mathrm{P}$ from ARC. BSA was from Sigma, Sphingosine kinase 1 form R\&D. Absolute, molecular biology grade ethanol was purchased from Fisher Scientific (Pittsburgh, PA). Plasticized polyvinyl chloride (PVC) endotracheal tubes $(8.0 \mathrm{~mm})$ were purchased from Cardinal Health (Dublin, OH). Silver-coated endotracheal tubes $(8.0 \mathrm{~mm})$ were from Bard Medical (Covington, GA). PVC coverslips $(24 \times 60 \mathrm{~mm})$ were purchased from Electron Microscopy Sciences (Hatfield, PA). Small PVC vein catheters (21 gauge; Braun Melsungen, Melsungen, Germany) were used in the mouse experiments. Three different bacterial species were used: Two strains of $S$. aureus, i.e., the methicillin-resistant strain USA 300 and a multi-resistant clinical isolate [27], a clinical isolate of $A$. baumannii and 4 different $P$. aeruginosa strains, i.e., three clinical strains named 338, 345, and 762 [19], as well as the laboratory strain PAO-1. The $P$. aeruginosa strains 338 and 345 were mucoid strains isolated from patients with cystic fibrosis [15].

\section{Sphingolipid molecular crystal thin film coating}

Sphingolipid solutions were prepared by dissolving either sphingosine $(30 \mathrm{mM})$ or phytosphingosine $(30 \mathrm{mM})$ into organic solvents (i.e., hexane, acetone, or ethanol). Sphingosine or phytosphingosine was added to hexane, which was preheated to $60{ }^{\circ} \mathrm{C}$ in a water bath, or ethanol, which was preheated to $70{ }^{\circ} \mathrm{C}$. In some experiments, we used acetone as a solvent, which was preheated to $50{ }^{\circ} \mathrm{C}$. After addition of sphingosine, the solution was agitated and sonicated until the sphingosine aggregates were no longer visible and the solution was clear.

Endotracheal tube segments, vein catheters used as endotracheal tubes in mice and plastic coverslips were used as coating substrates. Endotracheal tube segments were prepared by cutting $1-\mathrm{cm}$ long sections of endotracheal tubes. Sphingolipid films were deposited onto the surface of the aforementioned substrates by dip coating the object into the heated sphingolipid solution prepared as above. The tube segments were manipulated using a 1-mL insulin needle stuck through the plastic and the coverslips were manipulated using straight Kelly forceps. The tube segments/coverslips were immersed in the solution for $1 \mathrm{~s}$, and then slowly withdrawn at a rate of $1 \mathrm{~cm} / \mathrm{s}$. Evaporative-induced deposition of the film occurred when the object was exposed to room temperature atmospheric conditions. The resultant films, thus, are not covalent polymers but rather are formed by a rapid crystallization and referred to as molecular crystal thin films. Of note, the plastic coverslips were less resistant to acetone and began to dissolve when dip coated, thus we employed $100 \%$ ethanol as the solvent. Ethanol or hexane proved to work equally well and compared to acetone, they are less likely to affect the structural integrity of the PVC tubes. So, we changed our coating process to use ethanol or hexane as our preferred solvent. Repeated dips of up to 10 times were utilized initially, but after coating optimization with ethanol or hexane as solvent, only one dip was necessary to achieve excellent coatings. 
Coating with sphingomyelin, ceramide, S1P, and phosphatidylcholine was done according to the above-described method with 30-mM solutions.

In vitro biofilm colonization: complete immersion assay

Endotracheal tube segments were tested for inhibition of bacterial adherence using a modified version of the biofilm colonization model $[28,29]$. P. aeruginosa and A. baumannii were grown overnight on trypticase soy agar (TSA), and S. aureus on TSA with $5 \%$ sheep's blood plates at $37{ }^{\circ} \mathrm{C}$. Bacterial suspensions were prepared by placing bacteria into 10 -mL trypticase soy broth (TSB) with sterile cotton tip applicators, and incubating on a 120 -rpm shaker at $37^{\circ} \mathrm{C}$ for $1 \mathrm{~h}$, diluting 1:10 in TSB, measuring absorbance at $550 \mathrm{~nm}$, and diluting with TSB using standard curves prepared for each bacterial strain to achieve 500 colony forming units (CFU)/ $\mathrm{mL}$ concentration. Sphingolipid-coated, uncoated, or vehiclecoated endotracheal tube segments were immersed in $2-\mathrm{mL}$ bacterial suspension placed in 24-well plates and incubated for $12 \mathrm{~h}$ at $37^{\circ} \mathrm{C}$. Endotracheal tube segments were rinsed in $100 \mathrm{~mL}$ HEPES/Saline (H/S) $(132 \mathrm{mM} \mathrm{NaCl}, 20 \mathrm{mM}$ HEPES [pH 7.4], $5 \mathrm{mM} \mathrm{KCl,} 1 \mathrm{mM} \mathrm{CaCl} 2,0.7 \mathrm{mM} \mathrm{MgCl}_{2}$, $0.8 \mathrm{mM} \mathrm{MgSO}_{4}$ ) at $37^{\circ} \mathrm{C}$ and agitated at $125 \mathrm{rpm}$ for $30 \mathrm{~min}$. Segments were then placed in $10-\mathrm{mL}$ sterile $\mathrm{H} / \mathrm{S}$ in test tubes and sonicated at $37{ }^{\circ} \mathrm{C}$ in a bath sonicator for $10 \mathrm{~min}$ to remove adherent bacteria. Test tubes were vortexed for $5 \mathrm{~s}$ and the H/S serially diluted, plated on LB plates and incubated overnight. Bacterial CFU were counted and the total number of bacteria adherent to the $1-\mathrm{cm}$ endotracheal tube segments was calculated.

\section{In vitro biofilm colonization: variation on ISO 22196 and durability testing}

Plastic coverslips were tested for the inhibition of bacterial adherence using a modified version of the international standard for measurement of antibacterial activity on plastics and other non-porous surfaces, ISO 22196. Bacteria were prepared as described above to a concentration of $1 \times 10^{6} \mathrm{CFU} / \mathrm{mL}$. Ten microliters, i.e., 10,000 CFU, of bacterial suspension was then placed on the sphingolipid- or ethanol-coated portion of the coverslips and covered with a $2 \mathrm{~cm} \times 3 \mathrm{~cm}$ low-density polyethylene (LDPE) plastic film and incubated for $24 \mathrm{~h}$ at $37^{\circ} \mathrm{C}$. The plastic film was removed and the plastic coverslips rinsed to remove planktonic bacteria. The coverslips were then placed into a drying rack and incubated in humidified air at $37^{\circ} \mathrm{C}$ for $12 \mathrm{~h}$. Coverslips were placed into $10-\mathrm{mL}$ sterile $\mathrm{H} / \mathrm{S}$ in test tubes and sonicated at $37{ }^{\circ} \mathrm{C}$ in a bath sonicator for $10 \mathrm{~min}$ to remove adherent bacteria. Test tubes were vortexed for $5 \mathrm{~s}$ and the H/S serially diluted, plated on LB plates, and incubated overnight. Bacterial CFU were counted and the total amount of bacteria adherent to the coverslips was calculated.

To study the durability of the coating against bacterial adherence we inoculated the coated portion of the coverslip with additional bacteria after 24 and $48 \mathrm{~h}$. Bacteria were prepared the same as for the initial inoculation $\left(1 \times 10^{6} \mathrm{CFU} / \mathrm{mL}\right)$. The LDPE plastic film was lifted, $10 \mu \mathrm{L}(10,000 \mathrm{CFU})$ was pipetted onto the coated surface, and the LDPE film was replaced. The coverslips were incubated again for $24 \mathrm{~h}$ and the inoculation was again repeated at $48 \mathrm{~h}$. After $72 \mathrm{~h}$, the coverslips were rinsed in $\mathrm{H} / \mathrm{S}$ to remove planktonic bacteria, placed in drying racks and incubated for $12 \mathrm{~h}$ at $37{ }^{\circ} \mathrm{C}$, sonicated in sterile $\mathrm{H} / \mathrm{S}$ for $10 \mathrm{~min}$, diluted, plated, and quantification of adherent bacteria was performed.

In order to visualize the adherent bacteria after $24 \mathrm{~h}$, coverslips were removed from the incubator after being rinsed and dried in the humidifier for $12 \mathrm{~h}$. The adherent bacteria were heat-fixed to the coverslips by quickly passing over a Bunsen burner. The coverslips were then immersed in crystal violet for $1 \mathrm{~min}$, serially rinsed in $\mathrm{H}_{2} \mathrm{O}$, and mounted with VectaMount permanent mounting media. Slides were imaged by light microscopy using a Zeiss Axioimager M.2 microscope.

\section{In vitro prevention of bacterial biofilm formation}

Endotracheal tubes in vivo are exposed to a series of small volume bacterial inoculants in the form of bacteria-containing oral secretions. To investigate the effects of sphingosine and phytosphingosine on biofilm formation on endotracheal tubes mimicking in vivo conditions, tube segments were coated as described above, bacterial suspensions were prepared and endotracheal tube segments were challenged with 10,000 CFU pathogenic bacteria in $10 \mu \mathrm{L}$ and incubated for $24 \mathrm{~h}$. Adherent bacteria were then released from the surface and quantified.

In addition, $10^{5}$ CFU P. aeruginosa strains 338,345 , or PAO-1 were grown in a 24-well for $48 \mathrm{~h}$, washed 3 times in $\mathrm{H} / \mathrm{S}$, resuspended in $200 \mu \mathrm{L} \mathrm{H} / \mathrm{S}$, and adherent bacteria in biofilms were removed from the plate by scraping and by vigorous pipetting. Biofilm formation was confirmed on an additional plate by a spectrophotometric method: Plates were dried for $1 \mathrm{~h}$ at $60^{\circ} \mathrm{C}$, stained with crystal violet staining for 5 min, dried for $30 \mathrm{~min}$ at $37^{\circ} \mathrm{C}$, washed with $\mathrm{H}_{2} \mathrm{O}$, and the absorbance was determined at $492 \mathrm{~nm}$ using a microplate reader. Bacteria from all wells were combined and $20 \mu \mathrm{L}$ of the suspension was added to sphingosine-coated endotracheal tubes pieces. The plastic tubes were coated as above in $30 \mathrm{mM}$ sphingosine in ethanol. Samples were incubated at $37^{\circ} \mathrm{C}$ for $1 \mathrm{~h}$, bacteria were washed off with $1 \mathrm{~mL}$ of $\mathrm{H} / \mathrm{S}$ and sonication, plated, and CFU were counted after overnight growth.

\section{In vitro killing assay}

Small parts of the tubes were coated with sphingosine or phytosphingosine as above or left uncoated or were treated with $\mathrm{C}_{2} \mathrm{H}_{5} \mathrm{OH}$ only, placed into wells of a 24-well plate and $10^{4} \mathrm{CFU}$ of $P$. aeruginosa, A. baumannii, or $S$. aureus was 
pipetted as a small drop $(5 \mu \mathrm{l})$ onto the tube. The samples were incubated for $60 \mathrm{~min}$ in a humidified atmosphere, $500 \mu \mathrm{l} \mathrm{TSB}$ were added, and the bacteria were allowed to grow for $1 \mathrm{~h}$. Aliquots of the cultures were then plated and CFU were determined after growth $\mathrm{o} / \mathrm{n}$.

\section{Characterization of sphingolipid coating of endotracheal tubes}

Segments of coated endotracheal tubes, as described above, stained with $0.1 \%$ osmium tetroxide in $\mathrm{H}_{2} \mathrm{O}$ for 30 min, rinsed in $\mathrm{H}_{2} \mathrm{O}$ for $5 \mathrm{~min}$, dried, cut to fit on standard aluminum specimen mounts, and placed on the mounts using conductive tape. Mounted segments were then sputter-coated with gold/ platinum for $15 \mathrm{~s}$ and imaged using scanning electron microscopy (SEM) (FEI/Phillips XL-30 SEM). To study the durability of the coating in aqueous solutions samples were immersed in $\mathrm{H}_{2} \mathrm{O}, \mathrm{H} / \mathrm{S}$, or PBS for either $12 \mathrm{~h}$ or 7 days at $37^{\circ} \mathrm{C}$. Samples were then stained and imaged by SEM.

\section{Quantification of sphingolipids on endotracheal tubes and in tracheal tissue: mass spectrometry}

Sphingosine was extracted from coated plastic surfaces by a one-step lipid extraction. Briefly, the plastic piece was transferred into a siliconized glass tube and sphingosine was extracted by addition of $10 \mathrm{~mL}$ methanol and sonication on ice for $1 \mathrm{~h}$. After centrifugation, the lipid extract was diluted with methanol and 50 pmol of C17-sphingosine was added as internal standard. Tissues were processed as previously described [30]. Briefly, samples of murine trachea were homogenized in aqueous-buffered solution on ice using a Bead Ruptor 12 (Omni International, Kennesaw, GA). Aliquots of the homogenates $(40 \mu \mathrm{L})$, which corresponded to tissue equivalents of $1 \mathrm{mg}$, were subjected to lipid extraction using $1.5 \mathrm{~mL}$ methanol/chloroform $(2: 1, v / v)$. The extraction solvent contained $\mathrm{d}_{7}$-sphingosine (Avanti Polar Lipids, Alabaster, $\mathrm{AL})$ as internal standard. Chromatographic separation of sphingosine was achieved by reversed-phase high-performance liquid chromatography (HPLC) (Agilent 1260 series, Agilent Technologies, Waldbronn, Germany) using either an X-Bridge C18 $(4.6 \times 150 \mathrm{~mm}, 3.5 \mu \mathrm{m}$; Waters, Eschborn, Germany) or a ZORBAX Eclipse Plus C8 $(2.1 \times 150 \mathrm{~mm}$, $3.5 \mu \mathrm{m}$; Agilent) separation column. Water (eluent A) and acetonitrile/methanol (1:1, v/v; eluent $\mathrm{B})$, both acidified with $0.1 \%$ formic acid, were used as eluents. The HPLC column effluent was transferred into an Agilent 6490 triple quadrupole-mass spectrometer via an electrospray ion source interface operating in the positive ion mode (ESI+). The following ion source parameters were used: drying gas temperature $290{ }^{\circ} \mathrm{C}$, drying gas flow $11 \mathrm{~L} / \mathrm{min}$ of nitrogen, sheath gas temperature $380{ }^{\circ} \mathrm{C}$, sheath gas flow $12 \mathrm{~L} / \mathrm{min}$ nitrogen, nebulizer pressure 35 psi, capillary voltage $4500 \mathrm{~V}$, and nozzle voltage $2000 \mathrm{~V}$. Ion funnel parameters were: high pressure RF voltage $110 \mathrm{~V}$ and low pressure RF voltage $80 \mathrm{~V}$. The following selected reaction monitoring (SRM) transitions were used for quantification (collision energies in parentheses): $\mathrm{m} / \mathrm{z}$ $300.3 \rightarrow 282.3(8 \mathrm{eV})$ for sphingosine, $\mathrm{m} / \mathrm{z}, 286.3 \rightarrow 268.3$ $(8 \mathrm{eV})$ for C17-sphingosine, and $m / z, 307.3 \rightarrow 289.3(8 \mathrm{eV})$ for $\mathrm{d}_{7}$-sphingosine. Quantification was performed with MassHunter Software (Agilent Technologies). Determined sphingolipid amounts were normalized to the actual protein content of the tissue homogenate used for extraction.

\section{Quantification of sphingosine on endotracheal tubes: sphingosine kinase assay}

Sphingosine from pieces of coated endotracheal tubes was extracted in $\mathrm{CHCl}_{3} / \mathrm{CH}_{3} \mathrm{OH} / 1 \mathrm{~N} \mathrm{HCl}(100: 100: 1, v / v / v)$, the lower phase was dried and resuspended in a detergent solution consisting of $7.5 \%[w / v]$ n-octyl glucopyranoside, $5 \mathrm{mM}$ cardiolipin in $1 \mathrm{mM}$ diethylenetriaminepentaacetic acid [DTPA]. The kinase reaction was initiated by the addition of 0.004 units sphingosine kinase (R\&D Systems, Germany) in $50 \mathrm{mM}$ HEPES (pH 7.4), $250 \mathrm{mM} \mathrm{NaCl}, 30 \mathrm{mM} \mathrm{MgCl}$, $1 \mu \mathrm{M}$ ATP, and $5 \mu \mathrm{Ci}\left[{ }^{32} \mathrm{P}\right] \gamma \mathrm{ATP}$ [Hartmann, Cologne, Germany; $3000 \mathrm{Ci} / \mathrm{mmol}$. Samples were incubated for $60 \mathrm{~min}$ at $37^{\circ} \mathrm{C}$ with shaking $(350 \mathrm{rpm})$, then extracted in $20 \mu \mathrm{l} 1 \mathrm{~N} \mathrm{HCl}, 800 \mu \mathrm{l} \mathrm{CHCl} / \mathrm{CH}_{3} \mathrm{OH} / 1 \mathrm{~N} \mathrm{HCl}$ (100:200:1, $v / v / v), 240 \mu \mathrm{CHCl}_{3}$, and $2 \mathrm{M} \mathrm{KCl}$. The lower phase was collected, dried, dissolved in $20 \mu \mathrm{L}$ of $\mathrm{CHCl}_{3}: \mathrm{CH}_{3} \mathrm{OH}(1: 1$, $v / v)$, and separated on Silica G60 thin layer chromatography (TLC) plates using $\mathrm{CHCl}_{3} / \mathrm{CH}_{3} \mathrm{OH} /$ acetic acid/ $\mathrm{H}_{2} \mathrm{O}$ (90:90:15:5, $v / v / v / v)$ for sphingosine. The TLC plates were analyzed using a phosphorimager. Sphingosine was quantified using a standard curve.

\section{In vivo infection experiments}

P. aeruginosa strains 338,345 , or 762 were grown overnight on TSA plates at $37^{\circ} \mathrm{C}$, and S. aureus on TSA plates supplemented with $5 \%$ sheep blood. Bacteria were removed from the plates, suspended in $40 \mathrm{~mL}$ TSA in an Erlenmeyer flask and the density of the bacteria was adjusted to $0.225 \mathrm{OD}$ at $550 \mathrm{~nm}$. Bacteria were then grown for $60 \mathrm{~min}$ at $37^{\circ} \mathrm{C}$ with $125 \mathrm{rpm}$. Bacteria were washed twice in $\mathrm{H} / \mathrm{S}$ and resuspended in $\mathrm{H} / \mathrm{S}$. The concentration was determined by measuring the OD at $550 \mathrm{~nm}$ using a standard curve and adjusted to $250,000 \mathrm{CFU} / \mu \mathrm{L}$.

Mice were anesthetized with i.p. xylazine and ketamine, the trachea was exposed, incised and a $21 \mathrm{G}$ plastic catheter was inserted for approximately $1 \mathrm{~cm}$ into the trachea. The catheter was coated with sphingosine in hexane or ethanol as described above or, as control, only treated with hexane or ethanol. Approximately $5 \mathrm{~mm}$ of the tube protruded from the trachea. The tube was fixed by ligation distal to the 
insertion site. After a 10-min equilibration, $5 \times 10^{5} \mathrm{CFU}$ $P$. aeruginosa strains $338,345,762$, or multi-resistant S. aureus in $2 \mu \mathrm{H} / \mathrm{S}$ were applied to the outlet of the tube. Bacteria were allowed to infect the lung for $45 \mathrm{~min}$. Mice were then sacrificed, the lung removed under aseptic conditions, homogenized in 3-mL sterile RPMI-1640 buffered with HEPES to $\mathrm{pH} 7.4$, aliquots were plated on LB plates and CFU were determined after overnight growth.

\section{Sphingosine kinase assays to measure surface sphingosine in tracheal epithelial cells and sphingosine in tracheal mucus}

To determine surface sphingosine in tracheal epithelial cells, mice were intubated with ethanol (control)- or sphingosinecoated tubes for $60 \mathrm{~min}$, sacrificed, the intubated part of the trachea immediately removed, opened carefully, and the inner epithelial leaflet was incubated with 0.001 units sphingosinekinase in $50 \mathrm{mM}$ HEPES (pH 7.4), $250 \mathrm{mM} \mathrm{NaCl}, 30 \mathrm{mM}$ $\mathrm{MgCl}_{2}, 1 \mu \mathrm{M}$ ATP, and $5 \mu \mathrm{Ci}\left[{ }^{32} \mathrm{P}\right] \gamma \mathrm{ATP}$ for $30 \mathrm{~min}$ at $30^{\circ} \mathrm{C}$. We ensured that the kinase buffer was only added to the luminal surface of the trachea.

To test whether sphingosine released from the coated tubes remained in the mucus on the tracheal epithelial cells or was also incorporated into the epithelial cells, we isolated trachea as above, but then washed the trachea 5 times in $500 \mu \mathrm{L} \mathrm{H} / \mathrm{S}$ to remove the mucus on top of the epithelial cells layer. We then performed the in situ kinase assay as above. Controls were trachea from mice intubated with sphingosine-coated tubes, but the trachea were not washed and immediately used for the in situ sphingosine kinase assay.

The kinase reaction was terminated by placing the trachea in $100 \mu \mathrm{H}_{2} \mathrm{O}$, followed by addition of $20 \mu \mathrm{L} 1 \mathrm{~N} \mathrm{HCl}, 800 \mu \mathrm{l}$ $\mathrm{CHCl}_{3} / \mathrm{CH}_{3} \mathrm{OH} / 1 \mathrm{~N} \mathrm{HCl}(100: 200: 1, v / v / v), 240 \mu \mathrm{L} \mathrm{CHCl}_{3}$, and $2 \mathrm{M} \mathrm{KCl}$. Phases were separated, the lower phase was dried, dissolved in $20 \mu \mathrm{L}$ of $\mathrm{CHCl}_{3}: \mathrm{CH}_{3} \mathrm{OH}(1: 1, v / v)$ and separated on Silica G60 thin layer chromatography (TLC) plates using $\mathrm{CHCl}_{3} / \mathrm{CH}_{3} \mathrm{OH} /$ acetic acid/ $\mathrm{H}_{2} \mathrm{O}$ (90:90:15:5, $v / v / v / v)$ to develop the plates. The TLC plates were analyzed on a Fuji-phosphorimager and sphingosine amounts were calculated using a standard curve.

In addition, we also determined sphingosine in the wash buffer of the trachea. To this end, a 200- $\mu$ l aliquot of the buffer was extracted with $\mathrm{CHCl}_{3} / \mathrm{CH}_{3} \mathrm{OH} / \mathrm{HCl}$ (100:100:1; $v / v / v)$, the organic phase was dried, resuspended in $20 \mu \mathrm{L}$ detergent solution, sonicated for $10 \mathrm{~min}$, and $100 \mu \mathrm{l}$ of the sphingosine kinase buffer were added. The samples were incubated for $60 \mathrm{~min}$ at $37^{\circ} \mathrm{C}, 20 \mu \mathrm{L} 1 \mathrm{~N} \mathrm{HCl}, 800 \mu \mathrm{L}$ $\mathrm{CHCl}_{3} / \mathrm{CH}_{3} \mathrm{OH} / 1 \mathrm{~N} \mathrm{HCl}(100: 200: 1, v / v / v)$, each $240 \mu \mathrm{l}$ $\mathrm{CHCl}_{3}$ and $2 \mathrm{M} \mathrm{KCl}$ were added and the samples were further processed as above.

\section{Sphingosine immunostainings to determine sphingosine in tracheal epithelial cells}

Mice were anesthetized and intubated with sphingosinecoated or ethanol-, i.e., control-coated tubes for $60 \mathrm{~min}$ as above. Additional controls were left untreated. Mice were sacrificed, the intubated part of the trachea or the trachea of the untreated controls were removed and immediately fixed with 4\% PBS-buffered paraformaldehyde (PFA, Roth, Karlsruhe, Germany) for $36 \mathrm{~h}$. The tissue was serially dehydrated with an ethanol to xylol gradient and then embedded in paraffin. Trachea were sectioned at $7 \mu \mathrm{m}$, dewaxed, rehydrated, and treated with pepsin (Digest All; \#003009, Invitrogen, Carlsbad, USA) for $30 \mathrm{~min}$ at $37^{\circ} \mathrm{C}$, washed each once with water and PBS and blocked for $10 \mathrm{~min}$ at room temperature with PBS, $0.05 \%$ Tween 20 (Sigma), and 5\% fetal calf serum (FCS). The samples were then incubated with antisphingosine antibodies (1:1000 dilution; Alfresa Pharma Corporation, Japan) in $\mathrm{H} / \mathrm{S}$ supplemented with $1 \% \mathrm{FCS}$ at room temperature for $45 \mathrm{~min}$. Samples were washed three times with PBS plus $0.05 \%$ Tween 20 and once with PBS. The tissue was secondarily labeled with Cy3-coupled antimouse IgM $\mathrm{F}(\mathrm{ab})_{2}$ fragments (Jackson Immunoresearch, West Grove, USA) in H/S, $1 \%$ FCS for $45 \mathrm{~min}$. The samples were again washed 3-times with PBS plus $0.05 \%$ Tween 20 and once with PBS and embedded in Mowiol. Samples were evaluated by confocal microscopy on a Leica TCS-SP5 confocal microscope using a $\times 40$ lens. All samples were measured at identical settings. Images were analyzed with Leica LCS software version 2.61 (Leica Microsystems, Mannheim, Germany). All data were quantified using Image $J$ and are expressed as arbitrary units (a.u.). We analyzed trachea from 6 mice per experimental group. In each sample, the fluorescence of 100 randomly chosen different tracheal epithelial cells was quantified. The control stainings with only Cy3coupled isotype control antibodies were very weak.

\section{Total sphingosine in the trachea after intubation}

To determine total sphingosine in trachea after intubation, mice were intubated for $60 \mathrm{~min}$ with ethanol-treated or sphingosine-coated tubes as above, the tube removed, the trachea isolated, and shock frozen. Sphingosine was quantified by mass spectrometry as above.

\section{In vivo stability experiments}

To test the in vivo stability of sphingosine coated onto endotracheal tubes, $21 \mathrm{G}$ tubes were coated with sphingosine in hexane or ethanol as described above or, as control, only treated with hexane or ethanol. Tubes were then inserted into the trachea of mice for $60 \mathrm{~min}$, removed, and stored for $24 \mathrm{~h}$ at room temperature. This procedure was repeated 4 times over 
4 days. We employed this repeated exposure, because it is difficult to obtain a stable anesthesia of mice over $4 \mathrm{~h}$ and, in addition, we also obtained information on stability of the coating over time. Controls were hexane- or ethanol-coated tubes that were also inserted and sphingosine-, hexane or ethanol-coated tubes that were not inserted and coated either together with the inserted tubes and stored for 4 days or tubes that were coated immediately prior to quantification of surface sphingosine. Sphingosine on the surface (inner and outer surfaces) was quantified by a sphingosine kinase assay as described above.

\section{In vivo toxicity of and induction of inflammation by sphingosine-coated catheters}

PVC tubes were coated with $30 \mathrm{mM}$ sphingosine as above and mice were intubated for $2 \mathrm{~h}$ as above. The trachea was removed, fixed with $4 \%$ PFA, embedded in paraffin, sectioned at $6 \mu \mathrm{m}$, and stained with H\&E and TUNEL (TMR-Red kit) according to the instructions of the vendor (Roche, Mannheim). To prove the function of the TUNEL, trachea sections were treated with DNAse for $30 \mathrm{~min}$ at $37^{\circ} \mathrm{C}$, which resulted in $100 \%$ TUNEL positive cells. In addition, paraffin sections were stained with Cy3-labeled anti-CD45 antibodies to detect any influx of leukocytes. To this end, the samples were dewaxed, blocked for $10 \mathrm{~min}$ in $5 \%$ fetal calf serum (FCS) in H/S, washed in PBS, stained for 45 min with antiGr1 antibodies (1:250 diluted in $\mathrm{H} / \mathrm{S}+1 \% \mathrm{FCS}, \mathrm{BD}$, Heidelberg, Germany), washed three times in PBS supplemented with $0.05 \%$ Tween 20, incubated with Cy3-labeled anti-rat IgG antibodies for $45 \mathrm{~min}$ (1:500 in $\mathrm{HS} / 1 \% \mathrm{FCS}$, Jackson-ImmunoResearch), washed again 3 times in PBS/ $0.05 \%$ Tween 20 and once in PBS, and embedded in Mowiol. As positive controls, i.e., to verify the anti-CD45 antibody staining, we used spleen sections. All samples were analyzed on a Leica TCS SL confocal microscopy.

The number of dead epithelial cells and the influx of leukocytes were quantified in 10 sections from each trachea. We analyzed 6 mice, i.e. a total of 60 sections. In each section, the entire epithelial cell layer and the submucosa of the trachea were investigated. Image $\mathrm{J}$ was used for analysis of the samples.

\section{Quantification and statistical analysis}

Data are expressed as arithmetic means $\pm \mathrm{SD}$. For the comparison of continuous variables from independent groups, we used one-way ANOVA followed by post hoc Student's $t$ tests for all pairwise comparisons, applying the Bonferroni correction for multiple testing. The $P$ values for the pairwise comparisons were calculated after Bonferroni correction. All values were normally distributed and the variances were similar. A $p$ value of 0.05 or less (two-tailed) was considered statistically significant. The sample size planning was based on the results of two-sided Wilcoxon-Mann-Whitney tests (free software: $G^{*}$ Power, Version 3.1.7, University of Duesseldorf, Germany). Investigators were blinded for histology experiments.

Acknowledgements The authors thank Daniel Herrmann for excellent technical assistance with the mass spectrometric analyses.

Author contributions APS performed the in vitro experiments, EG the in vivo experiments and kinase assays, FS and BK the mass spectrometry measurements. JB contributed to the in vitro studies. MS and BW did the histology and stainings. MJE, APS and EG designed the studies. JB, CCC, RMG, MK, KAB and SB contributed important technical details. All authors read and commented on the manuscript.

Funding information The study was supported by DFG-grant Gu 33534/1 to EG and the GRK 2098 to EG, KAB and BK and the United States Air Force, grant AF-FA8650-14-2-6B33 and U.S. Air Force School of Aerospace Medicine, contract number FA8650-10-2-6140 to APS and MJE.

\section{Compliance with ethical standards}

Conflict of interests The authors declare that they have no conflict of interest.

Open Access This article is distributed under the terms of the Creative Commons Attribution 4.0 International License (http:// creativecommons.org/licenses/by/4.0/), which permits unrestricted use, distribution, and reproduction in any medium, provided you give appropriate credit to the original author(s) and the source, provide a link to the Creative Commons license, and indicate if changes were made.

\section{References}

1. Kalanuria AA, Zai W, Mirski M (2014) Ventilator-associated pneumonia in the ICU. Crit Care (London, England) 18:208

2. Rello J, Ollendorf DA, Oster G, Vera-Llonch M, Bellm L, Redman R, Kollef MH (2002) VAP Outcomes Scientific Advisory Group, Epidemiology and outcomes of ventilator-associated pneumonia in a large US database. Chest 122:2115-2121

3. Alhazzani W, Almasoud A, Jaeschke R, Lo BW, Sindi A, Altayyar S, Fox-Robichaud AE (2013) Small bowel feeding and risk of pneumonia in adult critically ill patients: a systematic review and meta-analysis of randomized trials. Crit Care 17:R127

4. Morris AC, Hay AW, Swann DG, Everingham K, McCulloch C, McNulty J, Brooks O, Laurenson IF, Cook B, Walsh TS (2011) Reducing ventilator-associated pneumonia in intensive care: impact of implementing a care bundle. Crit Care Med 39:2218-2224

5. Kollef MH, Afessa B, Anzueto A, Veremakis C, Kerr KM, Margolis BD, Craven DE, Roberts PR, Arroliga AC, Hubmayr RD, Restrepo MI, Auger WR, Schinner R (2008) NASCENT Investigation Group, Silver-coated endotracheal tubes and incidence of ventilator-associated pneumonia: the NASCENT randomized trial. JAMA 300:805-813

6. Chastre J, Fagon J-Y (2012) Ventilator-associated pneumonia. Am J Respir Crit Care Med 165:867-903

7. Pneumatikos IA, Dragoumanis CK, Bouros DE (2009) Ventilatorassociated pneumonia or endotracheal tube-associated pneumonia? 
An approach to the pathogenesis and preventive strategies emphasizing the importance of endotracheal tube. Anesthesiology 110: 673-680

8. Costerton JW, Stewart PS, Greenberg EP (1999) Bacterial biofilms: a common cause of persistent infections. Science 284:1318-1322

9. Hori K, Matsumoto S (2010) Bacterial adhesion: from mechanism to control. Biochem Eng J 48:424-434

10. Bibel DJ, Aly R, Shinefield HR (1992) Antimicrobial activity of sphingosines. J Invest Dermatol 98:269-273

11. Bibel DJ, Aly R, Shah S, Shinefield HR (1993) Sphingosines: antimicrobial barriers of the skin. Acta Derm Venereol 73:407-411

12. Fischer CL, Walters KS, Drake DR, Dawson DV, Blanchette DR, Brogden KA, Wertz PW (2013) Oral mucosal lipids are antibacterial against Porphyromonas gingivalis, induce ultrastructural damage, and alter bacterial lipid and protein compositions. Int J Oral Sci 5:130-140

13. Pewzner-Jung Y, Tavakoli Tabazavareh S, Grassmé H, Becker KA, Japtok L, Steinmann J, Joseph T, Lang S, Tuemmler B, Schuchman EH, Lentsch AB, Kleuser B, Edwards MJ, Futerman AH, Gulbins E (2014) Sphingoid long chain bases prevent lung infection by Pseudomonas aeruginosa. EMBO Mol Med 6:1205-1211

14. Tavakoli Tabazavareh S, Seitz A, Jernigan P, Sehl C, Keitsch S, Lang S, Kahl BC, Edwards M, Grassmé H, Gulbins E, Becker KA (2016) Lack of sphingosine causes susceptibility to pulmonary Staphylococcus aureus infections in cystic fibrosis. Cell Physiol Biochem 38:2094-2102

15. Grassmé H, Henry B, Ziobro R, Becker KA, Riethmüller J, Gardner A, Seitz AP, Steinmann J, Lang S, Ward C, Schuchman EH, Caldwell CC, Kamler M, Edwards MJ, Brodlie M, Gulbins E (2017) $\beta 1$-integrin accumulates in cystic fibrosis luminal airway epithelial membranes and decreases sphingosine, promoting bacterial infections. Cell Host Microbe 21:707-718

16. Azuma MM, Balani P, Boisvert H, Gil M, Egashira K, Yamaguchi T, Hasturk H, Duncan M, Kawai T, Movila A (2018) Endogenous acid ceramidase protects epithelial cells from Porphyromonas gingivalis-induced inflammation in vitro. Biochem Biophys Res Commun 495:2383-2389

17. De Souza PR, De Andrade D, Cabral DB, Watanabe E (2014) Endotracheal tube biofilm and ventilator-associated pneumonia with mechanical ventilation. Microsc Res Tech 77:305-312

18. Rosen MJ, Kunjappu JT (2012) Surfactants and interfacial phenomena. 4th Edition. John Wiley \& Sons

19. Grassmé H, Jendrossek V, Riehle A, von Kürthy G, Berger J, Schwarz H, Weller M, Kolesnick R, Gulbins E (2003) Host defense against Pseudomonas aeruginosa requires ceramide-rich membrane rafts. Nat Med 9:322-330

20. Martin GE, Boudreau R, Couch C, Becker KA, Edwards MJ, Caldwell CC, Gulbins E, Seitz AP (2017) Sphingosine's role in epithelial host defense: a natural antimicrobial and novel therapeutic. Biochimie 141:91-96

21. Youngquist P, Carroll M, Farber M, Macy D, Madrid P, Ronning J, Susag A (2007) Implementing a ventilator bundle in a community hospital. J T Comm Qual Patient Saf 33:219-225

22. Hartmann M, Guttmann J, Müller B, Hallmann T, Geiger K (1999) Reduction of the bacterial load by the silver-coated endotracheal tube (SCET), a laboratory investigation. Technol Health Care 7: 359-370

23. Gil-Perotin S, Ramirez P, Marti V, Sahuquillo JM, Gonzalez E, Calleja I, Menendez R, Bonastre J (2012) Implications of endotracheal tube biofilm in ventilator-associated pneumonia response: a state of concept. Crit Care 16:R93

24. Vandecandelaere I, Matthijs N, Nelis HJ, Depuydt P, Coenye T (2013) The presence of antibiotic-resistant nosocomial pathogens in endotracheal tube biofilms and corresponding surveillance cultures. Pathog Dis 69:142-148

25. Becam J, Walter T, Burgert A, Schlegel J, Sauer M, Seibel J, Schubert-Unkmeir A (2017) Antibacterial activity of ceramide and ceramide analogs against pathogenic Neisseria. Sci Rep 7: 17627

26. LaBauve AE, Wargo MJ (2014) Detection of host-derived sphingosine by Pseudomonas aeruginosa is important for survival in the murine lung. PLoS Pathog 10:e1003889

27. Henry BD, Neill DR, Becker KA, Gore S, Bricio-Moreno L, Ziobro R, Edwards MJ, Mühlemann K, Steinmann J, Kleuser B, Japtok L, Luginbühl M, Wolfmeier H, Scherag A, Gulbins E, Kadioglu A, Draeger A, Babiychuk EB (2015) Biomimetic, toxin-sequestrating therapy for the treatment of severe invasive bacterial infections. Nat Biotechnol 33:81-88

28. Kuhn DM, George T, Chandra J, Mukherjee PK, Ghannoum MA (2002) Antifungal susceptibility of Candida biofilms: unique efficacy of amphotericin B lipid formulations and echinocandins. Antimicrob Agents Chemother 46:1773-1780

29. Raad II, Mohamed JA, Reitzel RA, Jiang Y, Dvorak TL, Ghannoum MA, Hachem RY, Chaftari AM (2011) The prevention of biofilm colonization by multidrug-resistant pathogens that cause ventilator-associated pneumonia with antimicrobial-coated endotracheal tubes. Biomaterials 32:2689-2694

30. Gulbins A, Schumacher F, Becker KA, Wilker B, Soddemann M, Boldrin F, Müller CP, Edwards MJ, Goodman M, Caldwell CC, Kleuser B, Kornhuber J, Szabo I, Gulbins E (2018) Antidepressants act by inducing autophagy controlled by sphingomyelin-ceramide. Mol Psychiatry 23:2324-2346

Publisher's note Springer Nature remains neutral with regard to jurisdictional claims in published maps and institutional affiliations. 